\title{
Inter-annual variability of surface ozone at coastal (Dumont d'Urville, 2004-2014) and inland (Concordia, 2007-2014) sites in East Antarctica
}

\author{
Michel Legrand $^{1,2}$, Susanne Preunkert ${ }^{1,2}$, Joël Savarino ${ }^{1,2}$, Markus M. Frey ${ }^{3}$, Alexandre Kukui ${ }^{4}$, Detlev Helmig ${ }^{5}$, \\ Bruno Jourdain ${ }^{1,2}$, Anna E. Jones ${ }^{3}$, Rolf Weller ${ }^{6}$, Neil Brough ${ }^{3}$, and Hubert Gallée ${ }^{1,2}$ \\ ${ }^{1}$ Université Grenoble Alpes, Laboratoire de Glaciologie et Géophysique de l'Environnement (LGGE), Grenoble, France \\ ${ }^{2}$ CNRS, Laboratoire de Glaciologie et Géophysique de l'Environnement (LGGE), Grenoble, France \\ ${ }^{3}$ British Antarctic Survey, Natural Environment Research Council, Cambridge, UK \\ ${ }^{4}$ Laboratoire Atmosphère, Milieux et Observations Spatiales (LATMOS), UMR8190, CNRS-Université de Versailles Saint \\ Quentin, Université Pierre et Marie Curie, Paris, France \\ ${ }^{5}$ Institute of Arctic and Alpine Research (INSTAAR), University of Colorado, Boulder, CO, USA \\ ${ }^{6}$ Alfred Wegener Institut für Polar und Meeresforschung, Bremerhaven, Germany
}

Correspondence to: Michel Legrand (michel.legrand@lgge.obs.ujf-grenoble.fr)

Received: 29 January 2016 - Published in Atmos. Chem. Phys. Discuss.: 26 February 2016

Revised: 26 May 2016 - Accepted: 10 June 2016 - Published: 1 July 2016

\begin{abstract}
Surface ozone has been measured since 2004 at the coastal East Antarctic site of Dumont d'Urville (DDU), and since 2007 at the Concordia station located on the high East Antarctic plateau. This paper discusses long-term changes, seasonal and diurnal cycles, as well as inter-annual summer variability observed at these two East Antarctic sites. At Concordia, near-surface ozone data were complemented by balloon soundings and compared to similar measurements done at the South Pole. The DDU record is compared to those obtained at the coastal site of Syowa, also located in East Antarctica, as well as the coastal sites of Neumayer and Halley, both located on the coast of the Weddell Sea in West Antarctica. Surface ozone mixing ratios exhibit very similar seasonal cycles at Concordia and the South Pole. However, in summer the diurnal cycle of ozone is different at the two sites with a drop of ozone in the afternoon at Concordia but not at the South Pole. The vertical distribution of ozone above the snow surface also differs. When present, the ozone-rich layer located near the ground is better mixed and deeper at Concordia (up to $400 \mathrm{~m}$ ) than at the South Pole during sunlight hours. These differences are related to different solar radiation and wind regimes encountered at these two inland sites. DDU appears to be the coastal site where the impact of the late winter/spring bromine chemistry is the weakest, but where the impact of elevated ozone lev-
\end{abstract}

els caused by $\mathrm{NO}_{x}$ snow emissions from the high Antarctic plateau is the highest. The highest impact of the bromine chemistry is seen at Halley and Neumayer, and to a lesser extent at Syowa. These three sites are only weakly impacted by the $\mathrm{NO}_{x}$ chemistry and the net ozone production occurring on the high Antarctic plateau. The differences in late winter/spring are attributed to the abundance of sea ice offshore from the sites, whereas those in summer are related to the topography of East Antarctica that promotes the katabatic flow bringing oxidant-rich inland air masses to the site. There appears to be a decreasing change in summer surface ozone at the two East Antarctic sites of Concordia and DDU over the most recent period (2004-2014 and 2007-2014). Further research, including continued monitoring, is needed at these two sites to better separate the effect of synoptic transport from possible change of $\mathrm{NO}_{x}$ snow emissions in response to recovery of the stratospheric ozone layer leading to penetration of more UV radiation to the surface.

\section{Introduction}

In remote environments such as the polar regions, natural processes, synoptic transport and/or downward transport from the stratosphere, are the primary processes in- 
fluencing the levels of tropospheric ozone. Consequently, ozone data from these high latitudes were first thought to be of interest in assessing ozone background levels and trends at hemispheric scales. In the Northern Hemisphere, the longest polar ozone record from Barrow $\left(71^{\circ} 19^{\prime} \mathrm{N}\right.$, $156^{\circ} 36^{\prime} \mathrm{W}, 8 \mathrm{~m}$ above sea level (a.s.l.)), shows a mean annual increasing rate of $0.05 \pm 0.08 \mathrm{ppbv} \mathrm{yr}^{-1}$ (Helmig et al., 2007a) between 1975 and 2005. An even lower increasing rate of $0.02 \pm 0.09 \mathrm{ppbv} \mathrm{yr}^{-1}$ (Helmig et al., 2007a) is reported for the longest polar record of the Southern Hemisphere available from the South Pole (1975-2005). Whereas these annual changes remain far lower than those reported at remote sites located at middle latitudes, and are not significantly different from zero at the $P>95 \%$ confidence level, the examination of seasonal trends revealed more significant changes in some locations at both polar regions (see the review from Helmig et al., 2007a). Interpretation of these seasonal trends are, however, not simple since they are controlled by several recently discovered local processes involving snow or sea ice coverage. For instance, an intriguing observation of sudden decreases of ozone in the Arctic in spring was reported in the pioneering study from Bottenheim et al. (1986). The most important identified mechanism for this phenomenon (also detected at the coastal Antarctic site of Neumayer; Crawford et al., 2001; Frieß et al., 2004) is the reaction of ozone with halogens originating from oceanic regions covered by sea ice (Oltmans et al., 1989; Barrie and Platt, 1997). Future changing sea ice conditions are thus expected to influence ozone trends in spring in polar regions (Oltmans et al., 2012).

Another process that influences ozone in the polar atmospheric boundary layer is related to the photodenitrification of the snowpack. This denitrification resulting in $\mathrm{NO}_{x}$ emissions in summer was identified over Greenland (Honrath et al., 1999) and Antarctica (Jones et al., 1999, 2000, 2001; Davis et al., 2001). In the case of Antarctica, the evidence for the subsequent production of ozone was first discussed for the South Pole (Crawford et al., 2001). Since the ozone column density controls the UV irradiation at the ground level, Jones and Wolff (2003) suggested that the development of the stratospheric ozone hole has enhanced $\mathrm{NO}_{x}$ snow emissions and ozone photochemical production in the South Pole boundary layer in the early 1980s. According to this hypothesis, the expected future slow recovery of the stratospheric Antarctic ozone layer would lead to a decreasing rate of ozone production in the lower troposphere over the Antarctic plateau, at least in spring.

In parallel to these year-round surface ozone studies, several research campaigns dedicated to the study of atmospheric oxidants were conducted, first in JanuaryFebruary 1994 at the coastal site of Palmer $\left(64^{\circ} 46^{\prime} \mathrm{S}\right.$, $64^{\circ} 03^{\prime} \mathrm{W}$ ) in the West Antarctic peninsula within the framework of the SCATE project (Sulfur Chemistry in the Antarctic Troposphere Experiment, Berresheim and Eisele, 1998). Later on, the CHABLIS (Chemistry of the Antarctic Bound- ary Layer and the Interface with Snow, Jones et al., 2008) project was conducted at Halley from January 2004 to February 2005. In addition to the $\mathrm{HO}_{x}$ chemistry, CHABLIS also targeted the halogen chemistry. The oxidative properties of the atmosphere of inland Antarctica were mainly investigated at the South Pole through the ISCAT (Investigation of Sulfur Chemistry in Antarctica) projects in 1998 (Davis et al., 2001) and 2000 (Davis et al., 2004), followed by the Antarctic Tropospheric Chemistry Investigation (ANTCI, Eisele et al., 2008) project in 2003. Studies of oxidants in the atmospheric boundary layer including ozone were also carried out in summer above the West Antarctic Ice Sheet (WAIS) as part of scientific overland traverses (Frey et al., 2005) and deep ice core drilling at WAIS Divide (Masclin et al., 2013).

With the exception of the Syowa site, for which the ozone year-round record exists since 1997 (Helmig et al., 2007a), the ozone documentation in the east part of Antarctica only started in the last decade with measurements initiated in 2004 at the coastal East Antarctic site of Dumont d'Urville (DDU), and in 2007 at the Concordia station located on the high East Antarctic plateau (Legrand et al., 2009). This latter study revealed some particularities of East Antarctica that influence surface ozone levels, such as frequent occurrence of katabatic flow and less sea ice coverage offshore from the coastline. That represented one motivation of the OPALE (Oxidant Production over Antarctic Land and its Export) initiative. The first OPALE campaign took place at DDU in 20102011, and results were published in four companion papers in the Journal of Geophysical Research (see Preunkert et al., 2012). Data obtained during the second campaign conducted at Concordia in 2011-2012 are discussed in a set of papers in a special issue for Atmospheric Chemistry and Physics of which this is one.

With the aim to better understand interactions between transport (vertical stability of the atmospheric boundary layer, synoptic transport) and chemical (XO and $\mathrm{NO}_{x}$ chemistry) processes that control the surface ozone Antarctic budget (and its future response to global climate change), this paper examines the most recent ozone records available from Antarctica. Examination focuses on data recently gained at the two East Antarctic sites of DDU (2004-2014) and Concordia (2007-2014), but also includes a comparison with those from the South Pole and other coastal sites located both in East and West Antarctica. Finally, this paper briefly shows synoptic conditions with respect to ozone levels that were encountered during the two OPALE campaigns conducted at DDU in summer 2010-2011 and Concordia in summer 2011-2012.

\section{Sites and methods}

At the coastal site of DDU $\left(66^{\circ} 40^{\prime} \mathrm{S}, 140^{\circ} 01^{\prime} \mathrm{E}, 40 \mathrm{~m}\right.$ a.s.l., Fig. 1), ozone measurements started in 2004, the inlet of the sampling line being located at $2 \mathrm{~m}$ above the ground level. 


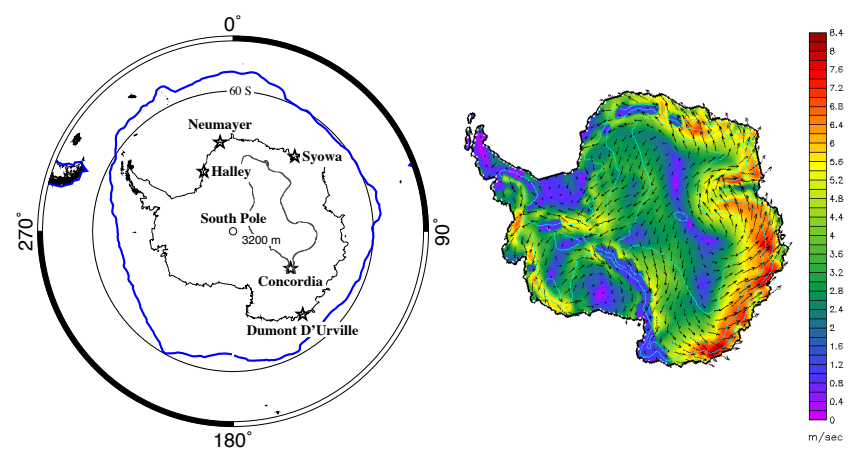

Figure 1. Left: map of Antarctica showing the inland sites of the South Pole and Concordia, the coastal sites of Dumont d'Urville and Syowa in East Antarctica, and Neumayer and Halley in West Antarctica. The blue line refers to the mean location of the sea ice edge in the end of winter (August) over the period 1981-2012 (NOAA_OI_SST_ V2 data provided by the NOAA/OAR/ESRL PSD, Boulder, Colorado, USA, http://www. esrl.noaa.gov/psd). Right: average wind speeds and wind vectors at $2 \mathrm{~m}$ a.g.l. in December 2009 and January 2010, as simulated by the MAR model nested in the European reanalyses (ERA-Interim) with a horizontal resolution of $40 \mathrm{~km}$.

Ozone monitoring was also initiated in 2007 at the inland site of Concordia $\left(75^{\circ} 06^{\prime} \mathrm{S}, 123^{\circ} 20^{\prime} \mathrm{E}, 3233 \mathrm{~m}\right.$ a.s.l., sometimes denoted DC) located $1100 \mathrm{~km}$ away from the nearest coast of East Antarctica (Fig. 1). At both sites, measurements have been made continuously with a UV absorption monitor (Thermo Electron Corporation, Franklin, Massachusetts, USA), model 49i at Concordia and 49c at DDU. Zero determinations and gas standard calibrations were made once a month. The data collected at $15 \mathrm{~s}$ intervals are here used as hourly, daily, and monthly averages. Note that, in the following, times refer to local times. At Concordia, where the instrument and the inlet of the sampling line are located at $17 \mathrm{~m}$ above the ground level, measurements were occasionally disturbed for a few hours when the wind was blowing from the generator building of the station (sector $20-50^{\circ} \mathrm{W}$ ). In addition, under very low wind speed conditions $\left(<2 \mathrm{~m} \mathrm{~s}^{-1}\right)$, measurements were disturbed for a few minutes when vehicles were leaving the station around 08:00 and 14:00 or back from work at 12:00 and 19:00. Such events can be easily identified by fast decreases of the ozone level in the $15 \mathrm{~min}$ record and were discarded from the hourly averaged data set (not shown). The effect of such sporadic contamination had, however, a limited effect on daily values. Among a total of 2687 daily values, 426 values were corrected (106 by more than 1 ppbv, 49 by more than 2 ppbv). At DDU, on some occasions the wind blew from the main combustion points of the station located between 0 and $90^{\circ} \mathrm{E}$ and between 310 and $340^{\circ} \mathrm{E}$, causing the plume of the station generator to impact the ozone sampling. These data were removed from the record. Among 3870 daily values, corrections were done for
1510 daily values (135 values with a correction exceeding $1 \mathrm{ppbv}, 28$ values with a correction ranging from 2 to $7 \mathrm{ppbv}$ ).

Concordia and DDU surface ozone data presented in this paper will be discussed and compared to those available at several other Antarctic sites. In particular, the Concordia record will be compared to data from the South Pole $\left(89^{\circ} 59^{\prime} \mathrm{S}, 2850 \mathrm{~m}\right.$ a.s.1.). The DDU record will be compared to those obtained at the coastal site of Syowa (SY), also situated in East Antarctica $\left(69^{\circ} 00^{\prime} \mathrm{S}, 39^{\circ} 35^{\prime} \mathrm{E}, 29 \mathrm{~m}\right.$ a.s.l.), as well as the coastal sites of Neumayer $\left(\mathrm{NM}, 70^{\circ} 39^{\prime} \mathrm{S}\right.$, $8^{\circ} 15^{\prime} \mathrm{W}, 42 \mathrm{~m}$ a.s.l.) and Halley (HA, $75^{\circ} 33^{\prime} \mathrm{S}, 26^{\circ} 32^{\prime} \mathrm{W}$, $30 \mathrm{~m}$ a.s.l.), both located at sea level in the Weddell Sea sector (West Antarctica, Fig. 1). Data from SP, SY, NM, and HA were retrieved from the WMO World Data Centre for Greenhouse Gases (http://ds.data.jma.go.jp/gmd/wdcgg/ cgi-bin/wdcgg) and updated with data from individual investigators. More details on data from the South Pole can be found in McClure-Begley et al. (2014). Details on ozone data from Syowa can also be found at http://ds.data.jma.go. jp/gmd/wdcgg/wdegg.html.

At Concordia, surface ozone data were complemented by investigation of the vertical ozone distribution in summer by using tethered balloons. Electrochemical concentration cell (ECC) sondes (ZECC, EN-SCI Corporation) and PTU sondes (RS92-SGPG, Vaisala) interfaced to RSA921OIF92 (Vaisala) for remote data transfer were used to document the vertical ozone distribution and meteorological conditions. Prior to each flight, ECC sondes were calibrated with the Ozoniser/Test Unit TSC-1 (Vaisala). Helium-filled $\left(2 \mathrm{~m}^{3}\right)$ tethered balloons (latex Totex, $1000 \mathrm{~g}$ ) were deployed. Ascent rates typically ranged from 0.2 to $0.8 \mathrm{~m} \mathrm{~s}^{-1}$, depending on the operator. Given the $25 \mathrm{~s}$ response time of the ECC sonde, delivered ozone data were delayed, causing a upward shift of the ozone profile by up to $20 \mathrm{~m}$. Vertical profiles were obtained from the end of December 2009 to 15 January 2010 and from 11 December 2011 to 9 January 2012. Under low wind conditions, balloons were able to reach heights up to $1010 \mathrm{~m}$ above ground level (a.g.l.) (i.e., $4225 \mathrm{~m}$ a.s.l.). This allowed the documentation of the vertical ozone change from the ground to above the planetary boundary layer (PBL), which grows to several hundreds of meters in the afternoon. High wind speeds $\left(>5 \mathrm{~m} \mathrm{~s}^{-1}\right.$ ) often prevented the balloon to reach more than $200 \mathrm{~m}$ a.g.l.; collected data, however, still proved useful to document the change of ozone from the ground to above the thin PBL encountered in the morning and at night. In this way, the vertical distribution of ozone was documented during the afternoon for 10 days and during night/early morning for 7 days.

To characterize the origin of air masses reaching the DDU and Concordia regions, 5-day backward trajectories were computed using the Hybrid Single-Particle Lagrangian Integrated Trajectory model ((Stein et al. 2015, available at: http://ready.arl.noaa.gov/HYSPLIT.php) . Meteorological data from Global Data Assimilation Process (available at ftp://arlftp.arlhq.noaa.gov/pub/archives/gdas1) were used as 

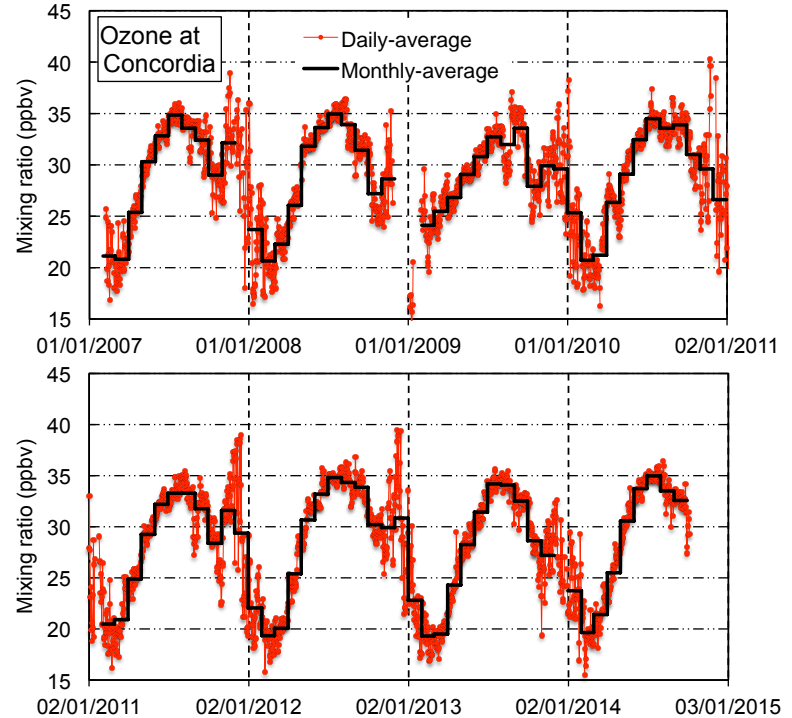

Figure 2. Daily averaged (red points) and monthly averaged (solid black line) surface ozone mixing ratio at Concordia from February 2007 to October 2014.

input, and the model was run every $6 \mathrm{~h}$ in backward mode for three different altitudes $(0,250$, and $500 \mathrm{~m}$ a.g.l.).

\section{Results and discussion of East Antarctic ozone records}

Daily and monthly averaged mixing ratios of ozone at Concordia and DDU are shown in Figs. 2 and 3, respectively. At Concordia, monthly averaged mixing ratios were calculated from February 2007 to September 2014, except for December 2008 and January 2009 over which very limited data were available due to a long breakdown of the analyser (Fig. 2). Furthermore, we do not calculate the monthly mean when a significant fraction of data was missing (30\% in December 2007, 36\% in January 2011, and 32\% in December 2013). At DDU, all monthly averaged mixing ratios are available from March to October 2014, except in December 2011 when $32 \%$ of data are not available (Fig. 3). At both sites, monthly means are the highest in the austral mid-winter, in July $(34.3 \pm 0.7 \mathrm{ppbv}$ at Concordia, $34.2 \pm 1.0 \mathrm{ppbv}$ at DDU) and August (33.5 $\pm 1.6 \mathrm{ppbv}$ at Concordia, $33.5 \pm 1.8 \mathrm{ppbv}$ at DDU). The summer minimum is observed in February at Concordia $(20.7 \pm 2.3 \mathrm{ppbv})$ and in January $(16.5 \pm 3.7 \mathrm{ppbv})$ at DDU. The overall seasonal cycle at Concordia and DDU, characterized by a winter maximum, is thus consistent with what is expected in such remote regions with a winter accumulation of ozone transported from other regions in the darkness, followed by photochemical destruction in spring and summer. At Concordia, however, the decreasing trend from July to October is interrupted by an increase in ozone levels in November, leading
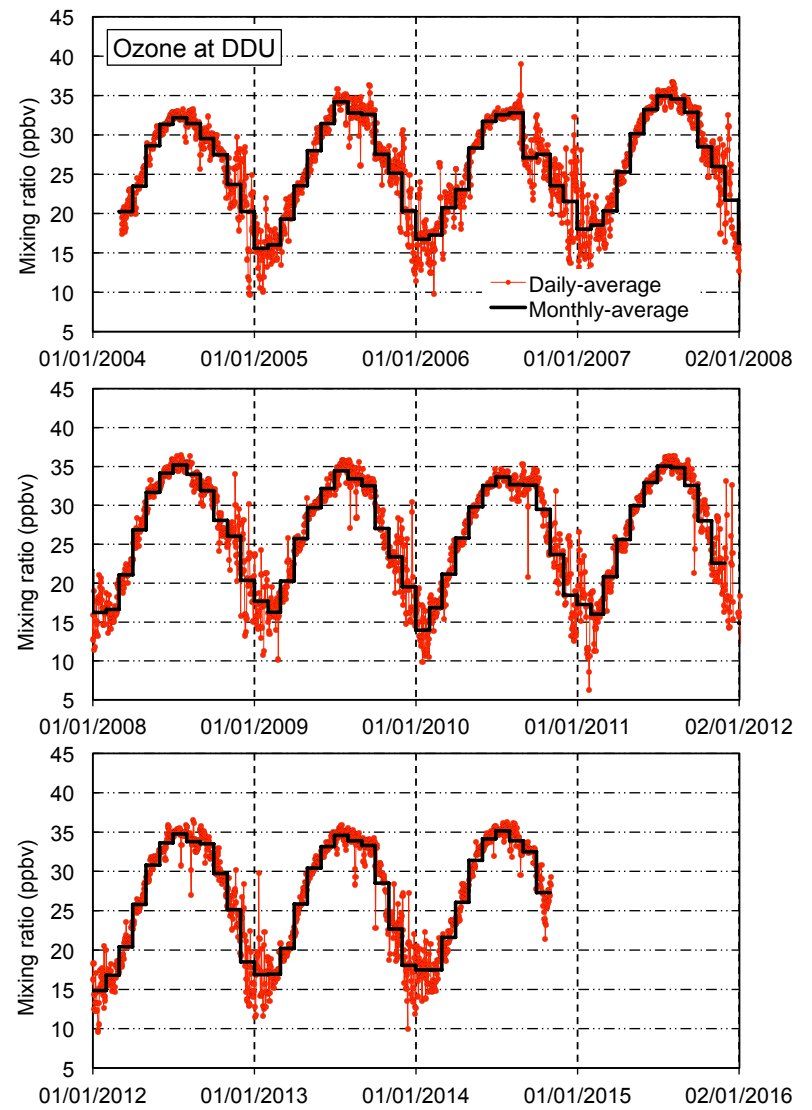

Figure 3. Daily averaged (red points) and monthly averaged (solid black line) surface ozone mixing ratio at Dumont d'Urville from March 2004 to October 2014.

to the presence of a secondary maximum (Fig. 2). At DDU, a November secondary maximum is not detected, but at that time, daily mean ozone values often exceed those observed in October (Fig. 3). In the following, we focus discussions on this summer time period at Concordia (Sect. 3.1) and DDU (Sect. 3.2). The patterns of the ozone seasonal cycle at Concordia and DDU are then compared and discussed with those observed at other Antarctic sites in Sects. 4 and 5, respectively.

\subsection{Concordia}

\subsubsection{Interannual summer variability at Concordia}

The observation of a secondary maximum of ozone in November-December at inland Antarctic sites was first reported for the South Pole by Crawford et al. (2001) and attributed to a photochemical production induced by the high $\mathrm{NO}_{x}$ levels in the atmospheric surface layer that are generated by the photodenitrification of the Antarctic snowpack (Davis et al., 2001). At Concordia, a secondary maximum in November-December 2007 was already reported by Legrand et al. (2009), suggesting that photochemical production of 


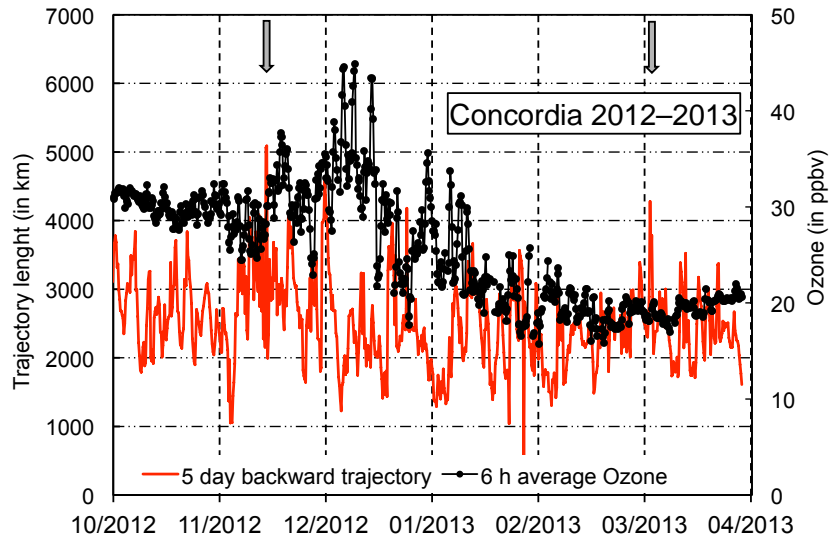

Figure 4. The $6 \mathrm{~h}$ averaged ozone mixing ratio and distance covered by the corresponding 5-day backward trajectory at Concordia (arrival at $0 \mathrm{~m}$ a.g.1.) from spring 2012 to fall 2013. The two grey arrows refer to the days 14 November and 5 March for which the air masses arriving at Concordia had traveled over the ocean (see Sect. 3.1.1).

ozone in summer takes place over a large part of the Antarctic plateau. As seen in Fig. 2, the November-December secondary maximum is clearly detectable in each of the 8 years of the record at Concordia. Also, the scatter of daily mean values at Concordia becomes far larger in summer (3.5 ppbv in November, $5.2 \mathrm{ppbv}$ in December, and $4.3 \mathrm{ppbv}$ in January) than over the rest of the year (from 2.3 ppbv in February and $2.0 \mathrm{ppbv}$ in October down to $0.7 \mathrm{ppbv}$ in July). In general, as seen in Fig. 4, a large daily variability is observed from mid-November to mid-January. At that time, ozone levels are enhanced in air masses having traveled over short distances during the last 5 days prior to their arrivals at Concordia. In contrast, prior to and after this summer period, ozone values remain unchanged in response to change of the travel distance of the air mass arriving at the site (Fig. 4). Note that backward trajectories arriving at Concordia shown in Fig. 4 (and in Fig. 5) are those calculated for arrival at $0 \mathrm{~m}$ a.g.l.; those arriving at the site at $250 \mathrm{~m}$ and $500 \mathrm{~m}$ a.g.l. (not shown) are similar.

Even when air masses arriving at Concordia had traveled far more than $1000 \mathrm{~km}$ (i.e., the distance from the coast), they rarely passed over the ocean during the 5 days before their arrival at the site. For instance, during summer 2012-2013, only on two occasions (14 November 2012 and 5 March 2013) had the air mass passed over the ocean 23 days prior to its arrival at Concordia as recognized in Fig. 4 by the long backward trajectories. The same is true for summers 2009-2010 and 2011-2012 reported in Fig. 5. Only two marine transport events occurred during summer 20092010 (15 and 19 November, Fig. 5a) and four during summer 2011-2012 (15, 21, and 24 December, 12-14 January, Fig. 5c). Note that this later event that is characterized by the longest trajectories $(6500 \mathrm{~km})$, encountered over the 8 years
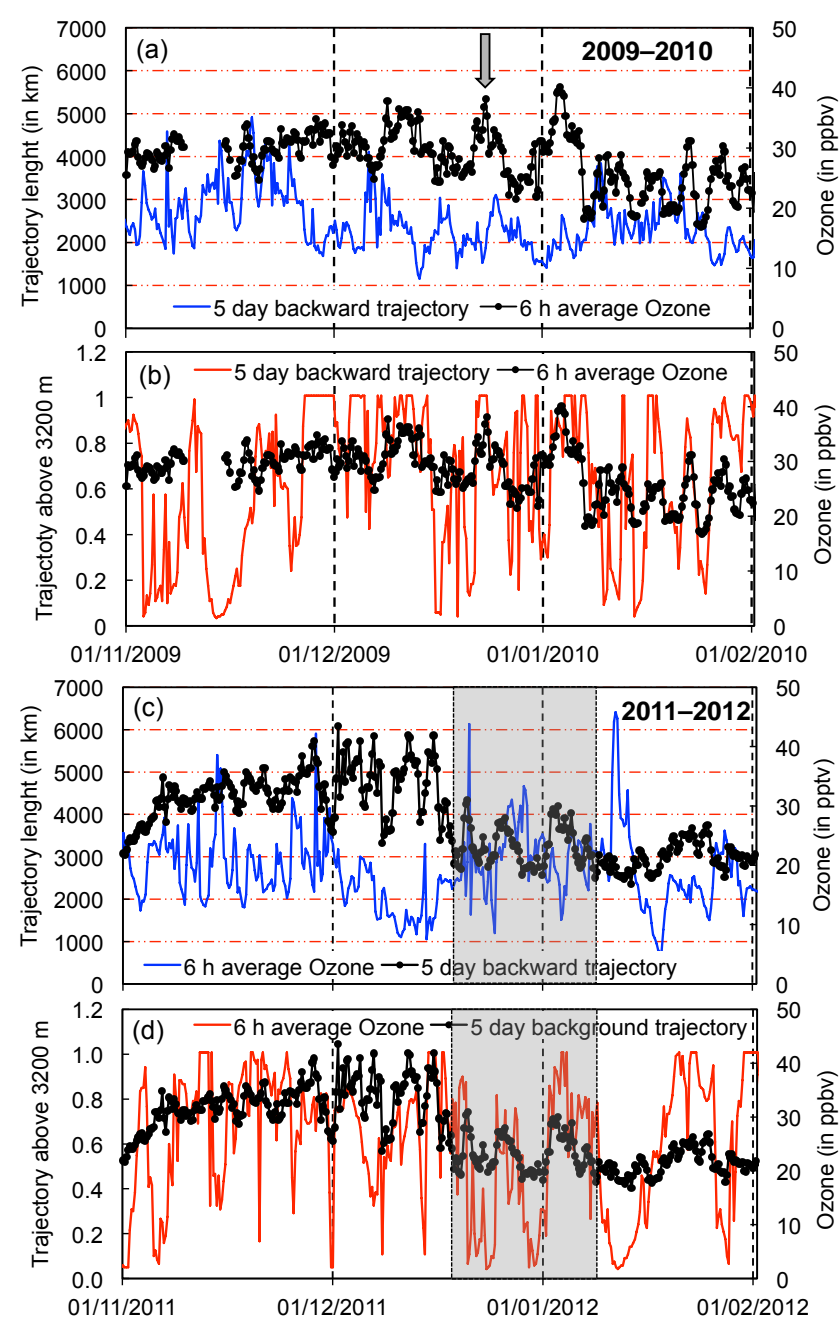

Figure 5. The $6 \mathrm{~h}$ averaged ozone mixing ratio (black dots) and the corresponding 5-day backward trajectory at Concordia from the austral spring 2009 to fall 2010 (a, b) and from spring 2011 to fall 2012 (c, d) (arrival at $0 \mathrm{~m}$ a.g.l.). The blue line is the trajectory length, the red line the fraction of the trajectory being above $3200 \mathrm{~m}$ elevation. The grey arrow (a) refers to the day 23 December during which the observed fast increase of ozone is discussed in Sect. 3.1.1. The grey area $(\mathbf{c}, \mathbf{d})$ denotes the sampling time period of the OPALE campaign.

of the record, coincides with a drop of ozone well below 20 ppbv.

Short trajectories, representing slow air transport, generally correspond to air masses having mainly traveled above the high Antarctic plateau. As seen in Fig. 5, ozone levels are particularly high when the air masses remained above $3200 \mathrm{~m}$ elevation. As an example, the fast increase of ozone seen in 2009 from 21 December (around $27 \mathrm{ppbv}$ ) to 23 December (around $34 \mathrm{ppbv}$, see the grey arrow in Fig. 5a) corresponds to an enhancement of the fraction of time spent by the air mass above $3200 \mathrm{~m}$ elevation (from $24 \%$ of time from 
(a) $\mathrm{O}_{3}<26 \mathrm{ppbv}$

(b) $26<\mathrm{O}_{3}<32 \mathrm{ppbv}$
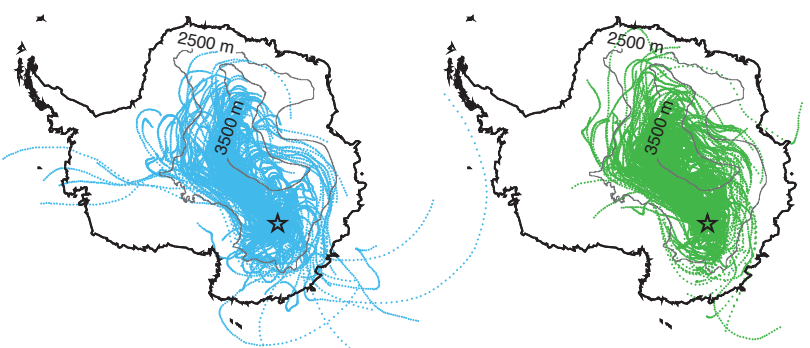

(c)

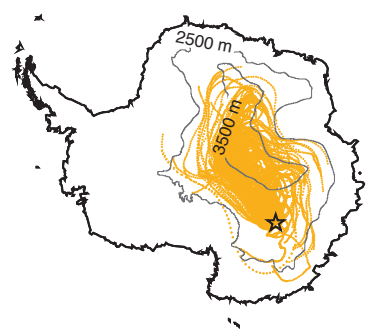

(d) $\mathrm{O}_{3}>38 \mathrm{ppbv}$

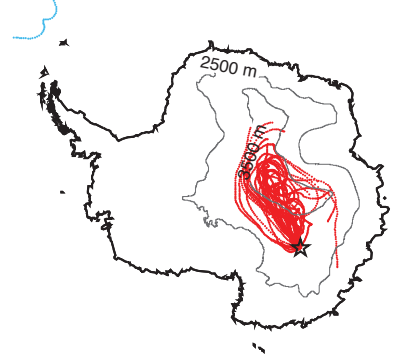

Figure 6. The 5-day backward trajectories for December at Concordia (from 2007 to 2014) corresponding to ozone mixing ratios of less than $26 \mathrm{ppbv}$ (blue lines in a), ranging between 26 and $32 \mathrm{ppbv}$ (green lines in b), between 32 and $38 \mathrm{ppbv}$ (yellow lines in $\mathbf{c}$ ), and higher than $38 \mathrm{ppbv}$ (red lines in d). All lines correspond to arrivals at $0 \mathrm{~m}$ a.g.1.

20:00 on 20 December to 08:00 on 22 December, to $98 \%$ of time from 08:00 on 22 December to 08:00 on 24 December), whereas the mean length of the 5-day backward trajectories remained similar over the two periods (2055 and $1960 \mathrm{~km}$, respectively). Note also that, as seen in Fig. 5c, the main OPALE campaign from 19 December 2011 to 9 January 2012 missed the period of high photochemical activity in the beginning of December (with hourly ozone values as high as 45 ppbv, i.e., the highest since 2007, not shown). Figure 5 clearly shows that, in contrast to 2009-2010, the second part of December 2011-2012 was characterized by air masses having traveled over rather long distances during the last 5 days prior to their arrivals at Concordia.

Even on the monthly scale, during the summer the influence of the air mass trajectory on ozone levels is still visible. For instance, as seen in Fig. 6 for December, the highest ozone values (higher than $38 \mathrm{ppbv}$ ) correspond to the shortest trajectories that almost always spent a significant time fraction over the highest part of the plateau (above $3500 \mathrm{~m}$ a.s.l.). Trajectories corresponding to ozone values ranging between 32 and 38 ppbv traveled mostly above $2500 \mathrm{~m}$ a.s.l. in the inner part of the continent. Finally, ozone values below $26 \mathrm{ppbv}$ are observed when the trajectories were among the longest,
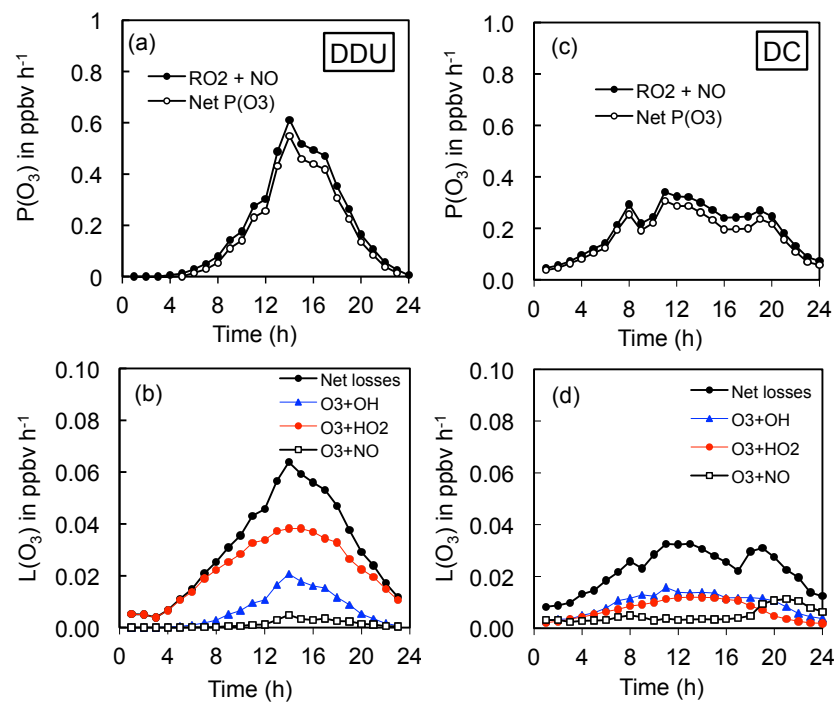

Figure 7. Ozone production (a, c) and loss $(\mathbf{b}, \mathbf{d})$ at DDU and Concordia calculated on the basis of observations summarized in $\mathrm{Ta}$ ble 1 . Time is local time.

sometimes starting from coastal regions or from the ocean (Fig. 6).

The preceding discussions suggests that the surface ozone mixing ratio at Concordia in summer is strongly influenced by the synoptic origin of the air masses, with the highest ozone values being observed when transport during the 5 days prior to its arrival was over the highest part of the Antarctic plateau. These transport conditions favor the photochemical production and/or accumulation of ozone related to snowpack emissions of $\mathrm{NO}_{x}$ in the air mass arriving at the site.

\subsubsection{Diurnal changes at the surface and in the lower troposphere in summer at Concordia}

Based on observed mixing ratios of $\mathrm{NO}$ and $\mathrm{RO}_{2}$ at Concordia (Table 1), an integrated local ozone production from the reaction of $\mathrm{NO}$ with $\mathrm{RO}_{2}$ of $4.7 \mathrm{ppbv}$ per day was calculated by Kukui et al. (2014). As seen in Fig. 7c and d, where the loss reactions of ozone with $\mathrm{OH}, \mathrm{HO}_{2}$, and $\mathrm{NO}$ (neglected by Kukui et al., 2014) were considered, the ozone net production still reaches 4 ppbv per day. In the following, we examine whether such a calculated ozone production rate of a few ppbv per day is consistent with observations. Given the importance of synoptic transport conditions on the day-to-day ozone variability (Sect. 3.1.1), the detection of an ozone trend over several days to estimate a mean local ozone production rate requires the search for a period of several days over which the transport pattern was invariant. As seen in Fig. 5a, from 27 to 30 November 2009, backward trajectories indicate transport of air masses consistently from the high Antarctic plateau (100\% of time above $3200 \mathrm{~m}$ a.s.l.), 
Table 1. Chemical measurements available from Concordia and Dumont d'Urville gained during the OPALE campaigns (in 2010-2011 at DDU, in 2011-2012 at Concordia) that were used to calculate production and losses of ozone reported in Fig. 7 (see Sect. 3.1.2). Values are $24 \mathrm{~h}$ averages.

\begin{tabular}{lrrl}
\hline & Concordia & DDU & References \\
\hline $\mathrm{RO}_{2}($ molecule cm & -3 \\
$\mathrm{HO}_{2}\left(\right.$ molecule $\left.\mathrm{cm}^{-3}\right)$ & $7 \times 10^{7}$ & $3.4 \times 10^{8}$ & Kukui et al. (2012, 2014) \\
$\mathrm{OH}$ (molecule $\left.\mathrm{cm}^{-3}\right)$ & $3.1 \times 10^{6}$ & $2.1 \times 10^{8}$ & Kukui et al. (2012, 2014) \\
$\mathrm{NO}$ (pptv) & 60 & $15^{*}$ & Kukui et al. (2012, 2014) \\
$\mathrm{O}_{3}$ (ppbv) & 24 & 21 & Preunkert et al. (2012), this work \\
\hline
\end{tabular}

* Estimated values from $\mathrm{NO}_{2}$ measurements.
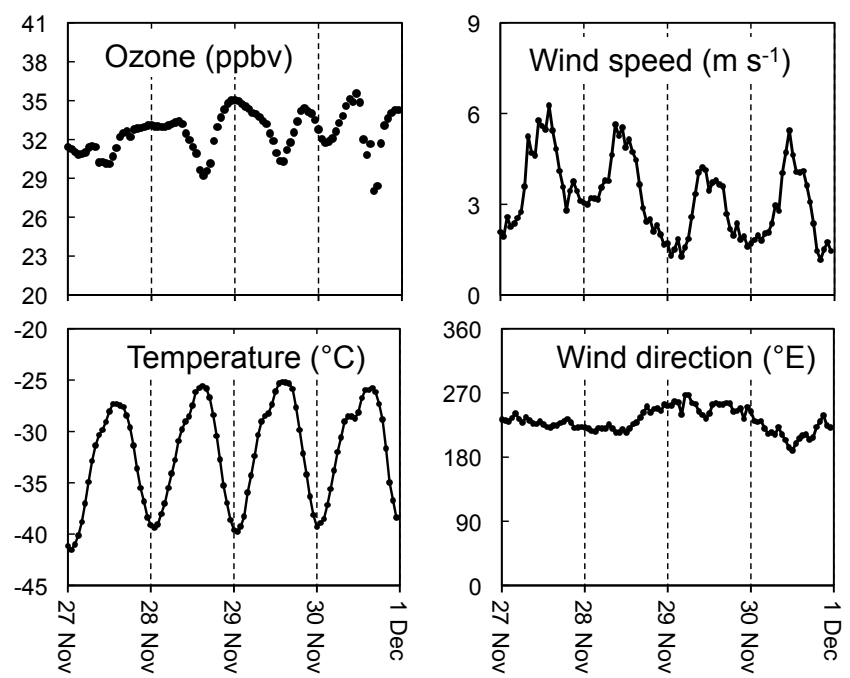

Figure 8. Hourly averaged surface ozone mixing ratio together with weather conditions at Concordia in summer over 4 days (2730 November 2009) characterized by stable continental conditions (see also Fig. 5a).

and over these 4 days surface wind direction remained unchanged (Fig. 8). An overall increase of around 4 ppbv in surface ozone can be observed (i.e., a mean increase of $1 \mathrm{ppbv}$ per day). Even estimated over a period with a slow synoptic transport, this ozone increase of 1 ppbv per day remains well below the expected local photochemical production. In fact, as seen in Fig. 8, the overall 4-day trend is interrupted each afternoon by a decrease of ozone mixing ratios by a few ppbv. As previously discussed by Legrand et al. (2009), this ozone decrease in the afternoon was attributed to an increase of the height of the PBL in response to the enhancement of the sensible heat flux in the afternoon at that site. Therefore, the local ozone production can only be evaluated from observations during the few hours before 11:00 when the PBL is still thin (less than $100 \mathrm{~m}$ ).
To better decipher the effect of ozone photochemical production and change of the vertical mixing over the course of the day, in the following we examine the vertical distribution of ozone obtained from some tethered balloon soundings in summer 2009-2010 and 2011-2012. In the afternoon, most of the time, the vertical ozone distribution at Concordia showed strong variations in the lowest $1000 \mathrm{~m}$ of the atmosphere with highest mixing ratios within the lowest hundreds of meters above the snow surface. The case of 4 January 2010 is reported in Fig. 9a, when the ozone mixing ratio approached $34 \mathrm{ppbv}$ in the lower $300 \mathrm{~m}$ and decreased steeply by more than $12 \mathrm{ppbv}$ within the next upper $100 \mathrm{~m}$. As shown by the vertical profile of potential temperature (Fig. 9b), this steep vertical change of ozone is clearly related to the presence of a well-mixed layer between the snow surface and $300 \mathrm{ma.g} .1$. and a very stable and stratified layer above. Over the 10 days over which flights reach high-enough elevations, the thickness of the ozone-rich PBL reached $270 \pm 85 \mathrm{~m}$ in the afternoon.

At night, the vertical profiles of the potential temperature showed a very thin (less than $70 \mathrm{~m}$ ) and stable PBL (see Fig. 9d) contrasting with the deeper and well-mixed daytime PBL. The change generally takes place after 17:00, when surface cooling generates negative buoyancy near the surface and a new boundary layer develops. This nighttime boundary layer is more stratified than the previous daytime boundary layer, which at that time was no longer connected with the surface and is now called the residual boundary layer. The residual boundary layer is generally several hundreds of meters deep, as seen in Fig. 9d. Its thickness and ozone content sometimes decreased over the course of the night. These changes of the residual boundary layer are somewhat variable likely due to change of wind conditions in these layers.

The onset of solar radiations in the early morning promotes the development of a well-mixed boundary layer. Its thickness is initially small (less than $50 \mathrm{~m}$ at 08:00, see Fig. 9f) and reaches a maximum of several hundreds of meters around 16:00 in the afternoon as a consequence of the enhancement of radiation and the subsequent increase of the sensible heat flux. As seen in Fig. 10, the growth of the PBL over the course of the day is associated with a change in the 

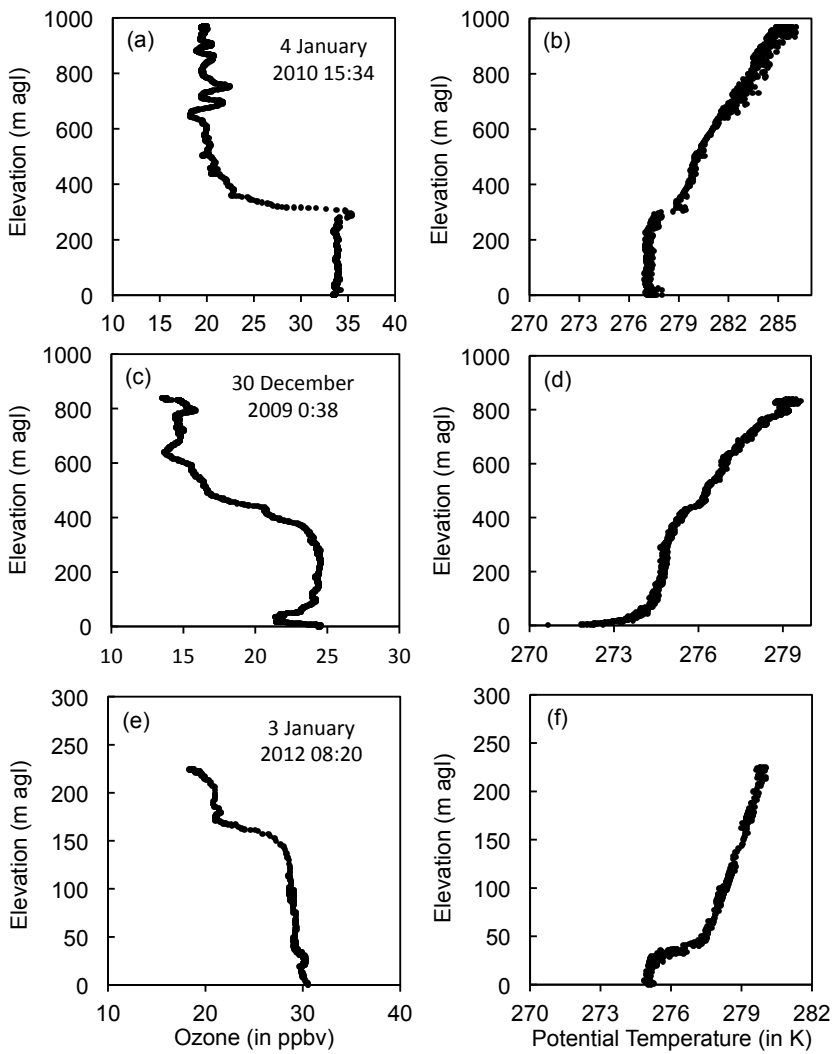

Figure 9. Examples of vertical distributions of ozone at Concordia in the afternoon (a), around midnight (c), and early morning (e) along with the corresponding potential temperature profiles $(\mathbf{b}, \mathbf{d}$, and $\mathbf{f}$, respectively). Dates are reported in local time and elevation in $\mathrm{m}$ a.g.l.

ozone vertical distribution. Ozone distribution shows a homogeneous mixing ratio within the entire boundary layer. For the examples reported in Fig. 10, we will examine if the ozone content of the boundary layer and its change from early morning to mid-afternoon are consistent with a photochemical ozone production in the range of a few tenths of ppbv per hour, as calculated for Concordia (see Fig. 7c). As seen in Fig. 10a and b, on 31 December 2009, the height of the boundary layer close to $278 \mathrm{~m}$ a.g.l. at the balloon flight of 14:53 was enhanced to $400 \mathrm{~m}$ a.g.l. at the next flight (15:31). The ozone mixing ratio that exhibits a homogeneous value within the entire boundary layer during the two soundings, dropped from $20.0 \mathrm{ppbv}$ (at 14:53) to $19.4 \mathrm{ppbv}$ (at 15:31). Since the decrease of the ozone mixing ratio between the two flights is simultaneous with an increase of the thickness of the well-mixed boundary layer, we have calculated the ozone amount present within the lower $467 \mathrm{~m}$ a.g.l. (i.e., the elevation above which ozone mixing ratios remained unchanged between the two flights, Fig. 10a). It is found that the ozone amount was higher during the second flight than the first flight, the difference corresponding to a net production of $0.35 \mathrm{ppbv}$ over $38 \mathrm{~min}$. The corresponding hourly increase of $0.55 \mathrm{ppbv}$ is consistent with the calculated photochemical production (on average $0.3 \mathrm{ppbv} \mathrm{h}^{-1}$, Fig. 7c) during the sunlight hours of the day at Concordia. Note that comparison of the change over time of the ozone amount present within the entire boundary layer with photochemical ozone production rates calculated using NO mixing ratio observed near the surface (as reported in Table 1) is justified. Indeed, at Concordia, vertical NO profiles also indicate homogeneous mixing ratios with gradients remained lower than $10 \mathrm{pptv}$ throughout the afternoon (12:00-18:00 LT), at least within the lower $100 \mathrm{~m}$ of the atmosphere (Frey et al., 2015).

Also interesting is the example reported in Fig. 10c and $\mathrm{d}$, showing a slight increase of ozone during mid-morning, followed by a strong decrease in the afternoon. The average ozone increase by $0.12 \mathrm{ppbv}$ from 0 to $130 \mathrm{~m}$ a.g.l. between the flight launched at 10:33 and the one at 11:24 can be attributed to a photochemical production close to $0.14 \mathrm{ppbv}$ per hour having acted within a boundary layer whose thickness remained close to $130 \mathrm{~m}$. In the following, we examine if the observed drop of ozone from $33 \mathrm{ppbv}$ in the morning to around $27 \mathrm{ppbv}$ at $13: 38$ is due to the growth of the PBL. The flight at 13:38 only documented the lowest $240 \mathrm{~m}$ a.g.l. but the potential temperature profile (Fig. 10d) suggests that, at that time, the top of the PBL was already higher than 240 m a.g.l. The height of the PBL simulated by the MAR model suggests a PBL height of 140 and $220 \mathrm{~m}$ for the two first flights and $490 \mathrm{~m}$ for the flight launched at 13:38. Details on the MAR model are given in this issue (Gallée et al., 2015a). In the following calculations, we have assumed a thickness of the PBL of $400 \mathrm{~m}$ at 13:38 (instead of $490 \mathrm{~m}$ simulated by MAR) to account for an overall tendency of the MAR model to overestimate the height of the PBL by a few tens of meters at that time of the day (Gallée et al., 2015a). The amount of ozone present within the lower $400 \mathrm{~m}$ at $10: 33$ was estimated by extrapolating the vertical gradient of ozone observed above $200 \mathrm{~m}$ a.g.l. during the flight at 10:33 (red curve in Fig. 10c). Assuming a well-mixed ozone level within the PBL at 13:38, an unchanged amount of ozone within the lower $400 \mathrm{~m}$ between 10:38 and 13:38 would imply an ozone mixing ratio of $26.3 \mathrm{ppbv}$ at $13: 38$. If accounting for a mean hourly ozone production of $0.3 \mathrm{ppbv}$, the $3 \mathrm{~h}$ lag between the first and third sounding leads to a mixing ratio of $27.2 \mathrm{ppbv}$ within the PBL at 13:38. This value is consistent with the mean mixing of $27.4 \mathrm{ppbv}$ observed within the lower $240 \mathrm{~m}$ during sounding at 13:38. Though the thickness of PBL during flight launched at 13:38 is not accurately known, it can be concluded that the large ozone decrease seen between 10:33 and 13:38 (from 33 to $27.4 \mathrm{ppbv}$ ) is mainly related to the growth of the PBL. Though further investigations with diurnal vertical profiling over the course of the day are clearly needed, this example suggests that the decrease of ozone mixing ratio often detected near the surface in the afternoon (Fig. 8) may be caused by dilution due to the increase in the boundary layer depth which counteracts the local ozone photochemical production. It also would explain 

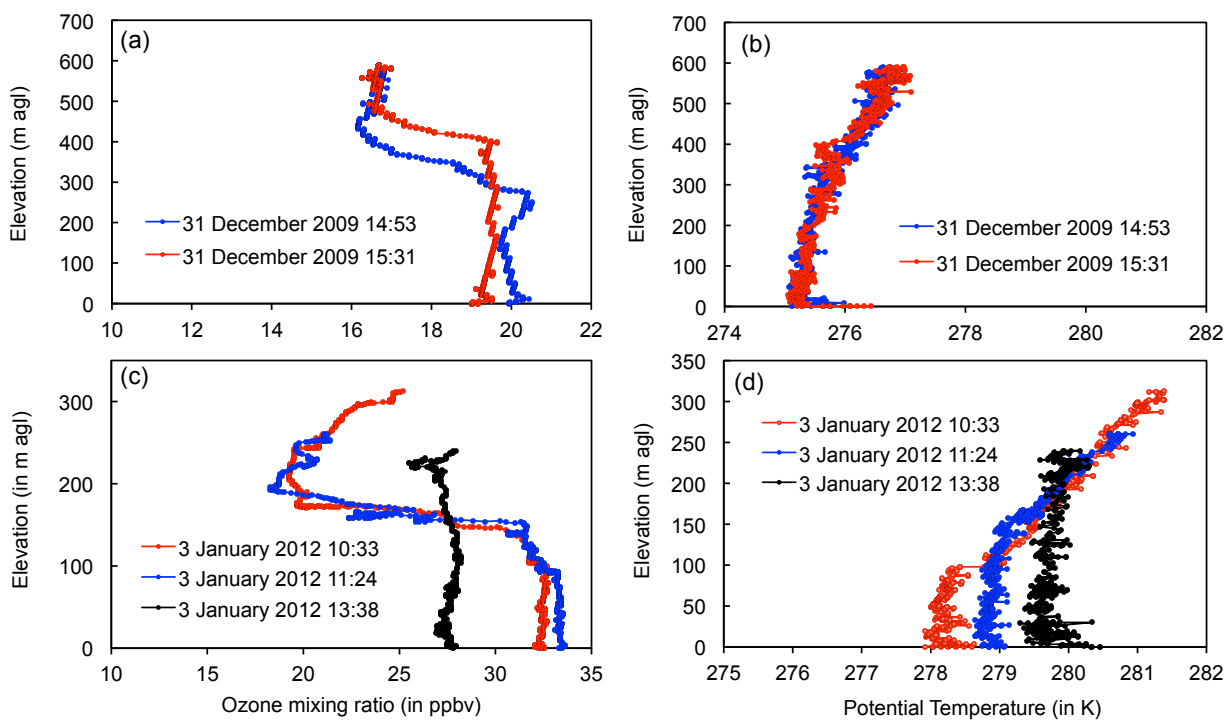

Figure 10. Examples of diurnal vertical ozone distribution changes at Concordia (during the afternoon in a, and from the morning to the afternoon in c), along with corresponding potential temperature profiles (b, d, respectively). Dates are reported in local time and elevation in m a.g.l.

why at Concordia the net accumulation of ozone produced photochemically never reaches 4 ppbv over $24 \mathrm{~h}$.

\subsection{DDU}

The occurrence of events with rather high ozone mixing ratios during November-December at DDU was already observed by Legrand et al. (2009) and attributed to frequent occurrence of katabatic transport to the site of oxidant-rich air masses originating from the high plateau.

As shown in Fig. 11, the ozone levels at DDU in summer are strongly dependent on the origin of air masses reaching the site. Ozone mixing ratios drop when the air masses had traveled most of the time over the ocean during the last 5 days prior to their arrival at the site. In contrast, highest ozone levels are observed in air masses having never traveled over the ocean and that remained 2-3 days above $3000 \mathrm{~m}$ a.s.l. over inland Antarctica. A particularly good example of the effect of the air mass origin on ozone levels is shown in Fig. 11a and $b$. This 2005-2006 summer started with a November month characterized by an absence of marine influence until the morning of 27 November, when a marine event started (see the grey left arrow in Fig. 11a). This marine event lasted to the afternoon of 29 November and was followed by a time period with air masses coming from the high East Antarctic plateau (from 29 November to 7 December in the morning). This well-marked change of air mass origin was accompanied by a large increase of the ozone mixing ratio by $10 \mathrm{ppbv}$ (from $18.7 \mathrm{ppbv}$ over 27-29 November to $28.5 \mathrm{ppbv}$ during first week of December). As seen in Fig. 11a and $\mathrm{b}$, during the second week of December air masses came neither from the ocean nor from the inland plateau. These air masses, that had traveled over the coastal region of the Antarctic continent during that time, contained similar levels of ozone as the marine transport $(19.4 \mathrm{ppbv}$ instead of $18.7 \mathrm{ppbv})$. This similar level of ozone in air masses having a pure marine origin or having traveled over margin regions of the Antarctic continent is consistent with the study from Frey et al. (2005) that showed that photochemical ozone production is not large over inland Antarctic regions located below about $2500 \mathrm{~m}$. A more recent study conducted in the interior of West Antarctica at the WAIS Divide (1766 ma.s.l.) also showed that the local ozone production is too small to explain the observed ozone variability and that events with increased surface ozone in summer are systematically linked to rapid ( $<3$ days) transport off the East Antarctic plateau via katabatic outflow (Masclin et al., 2013). The preceding sequence of changing air mass origin (ocean, Antarctic plateau above $3000 \mathrm{~m}$ a.s.l., and coastal regions of the Antarctic continent) was encountered again from 14 to 27 December, with ozone levels of $16.7 \mathrm{ppbv}$ between 14 December in the evening and 17 December in the morning (marine origin, see the grey right arrow in Fig. 11a), 23.6 ppbv between 17 and 21 December (continental origin), and $17.6 \mathrm{ppbv}$ between 21 and 27 December (coastal origin). Finally, December ended with another marine event during which ozone levels dropped to $12.7 \mathrm{ppbv}$. The strong dependence of the ozone summer levels on the origin of air masses reaching DDU is still clearly seen when all 5-day backward trajectories are plotted together, as done in Fig. 12 for December (from 2004 to 2014).

In contrast to conditions encountered in summer 20052006, during the OPALE campaign (26 December 2010 14 January 2011, Fig. 11c and d), less well-defined changes 


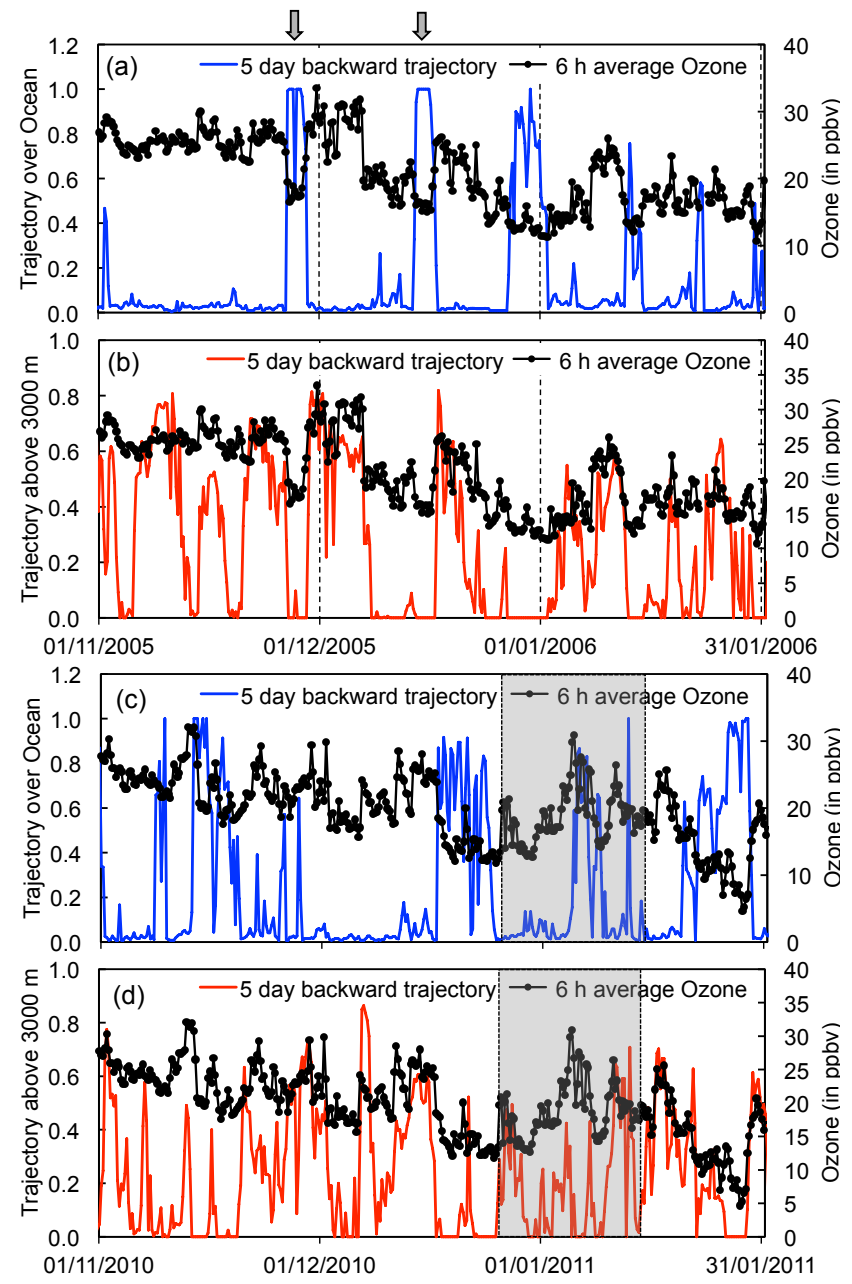

Figure 11. The $6 \mathrm{~h}$ averaged ozone mixing ratio (black dots) and the corresponding 5-day backward trajectory at DDU from spring 2005 to fall 2006 (a, b) and from spring 2011 to fall 2012 (c, d). The red and blue lines are the continental (above $3000 \mathrm{~m}$ a.s.l.) and marine residence time fractions of air masses arriving at DDU as deduced from the HYSPLIT model. The two grey arrows on panel a refer to the days 27-29 November and 14-17 December during which the observed fast decreases of ozone are discussed in Sect. 3.2. The time fractions are averages for the three different arrival heights. The grey area denotes the sampling time period of the OPALE campaign.

of transport conditions were observed. For instance, a pure marine regime only occurred for a few hours on the evening of 12 January followed by distinctly continental conditions for 2 days (12-14 January). In fact, as shown by Preunkert et al. (2012), the most dominant regime during the campaign was air masses' transport from the coastal regions of the Antarctic continent. In spite of these mixed conditions, in their study of $\mathrm{OH}$ radicals, Kukui et al. (2012) were able to identify the importance of the production of $\mathrm{OH}$ from $\mathrm{RO}_{2}$ recycling in air masses arriving preferentially from inland (a) $\mathrm{O}_{3}<17 \mathrm{ppbv}$

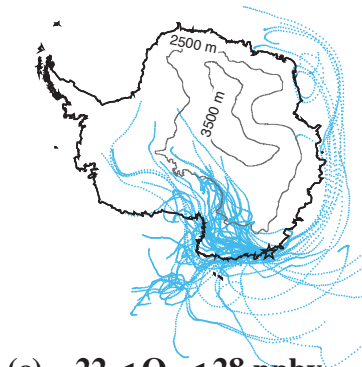

(c) $22<\mathrm{O}_{3}<28 \mathrm{ppbv}$

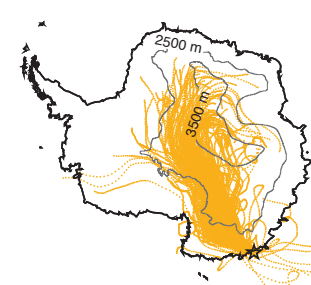

(b) $17<\mathrm{O}_{3}<22 \mathrm{ppbv}$

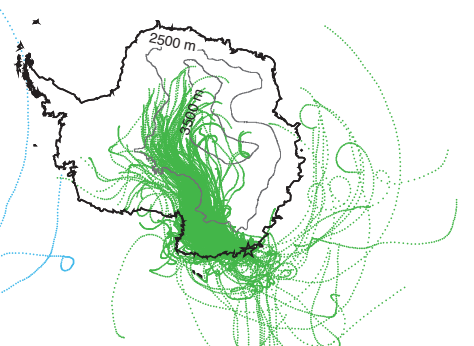

(d) $\mathrm{O}_{3}>28 \mathrm{ppbv}$

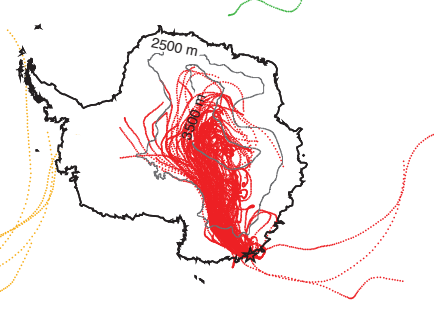

Figure 12. The 5-day backward trajectories for December at Dumont d'Urville (from 2004 to 2014) corresponding to ozone mixing ratios of less than 17 ppbv (blue lines in a), ranging between 17 and 22 ppbv (green lines in b), between 22 and 28 ppbv (yellow lines in c), and higher than $28 \mathrm{ppbv}$ (red lines in d). All lines correspond to arrivals at $0 \mathrm{~m}$ a.g.l.

Antarctica compared to those having been partly in contact with the ocean.

As can be seen in Fig. 7a, a mean local photochemical production close to $0.3 \mathrm{ppbvh}^{-1}$ is calculated during sunlight hours of the day at DDU. As seen in Table 1, the quite similar ozone photochemical production calculated at Concordia and DDU results from a 4 times lower mixing ratio of NO at DDU compared to Concordia that is compensated by larger $\mathrm{RO}_{2}$ concentrations $\left(3.4 \times 10^{8}\right.$ molecules $\mathrm{cm}^{-3}$ at DDU instead of $1.0 \times 10^{8}$ molecule $\mathrm{cm}^{-3}$ at Concordia). In contrast to the case of Concordia discussed in Sect. 3.1.2, at DDU, we never observe a detectable increasing ozone trend of a few ppb over successive days during which air masses were coming from inland Antarctica. That may be related to either an overestimation of the production or an underestimation of sinks. An overestimation of the production cannot be ruled out since $\mathrm{NO}$ was estimated from $\mathrm{NO}_{2}$ measurements done at DDU by applying the extended Leighton relationship (Grilli et al., 2013). As discussed by Frey et al. (2015), at Concordia the use of this relationship indicates that observed $\mathrm{NO}_{2}$ mixing ratios are higher than expected with respect to observed NO mixing ratios. If it is still the case in continental air masses reaching DDU, the ozone production from $\mathrm{NO}$ calculated on the basis of $\mathrm{NO}_{2}$ observations would be overestimated. The estimated net ozone reported in Fig. 7 neglected dry deposition at the two sites. Whereas this as- 

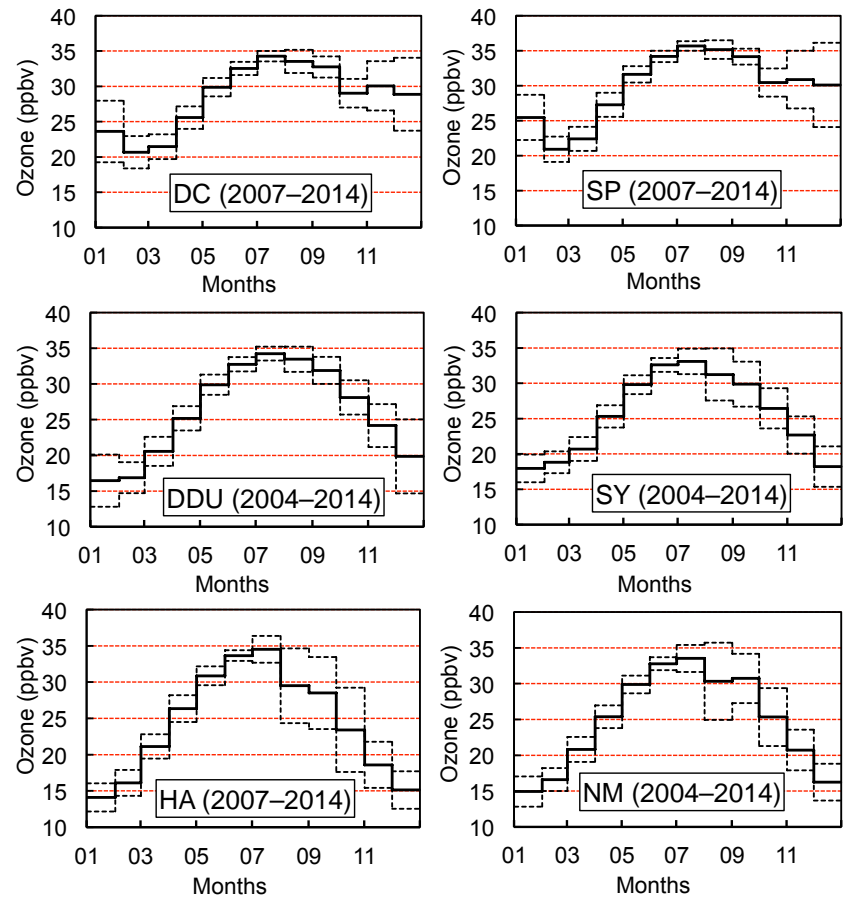

Figure 13. Monthly averaged ratios and standard deviations of ozone mixing ratios at Concordia (denoted DC), the South Pole (SP), Dumont d'Urville (DDU), Syowa (SY), Halley (HA), and Neumayer (NM). The standard deviations represent day-to-day variability.

sumption is likely correct for the cold snowpack present at in the Concordia region, it would not necessarily be correct at DDU given the nature of surrounding surface at the site in summer (open ocean, rocks, soils, and wet snow) on which larger ozone dry deposition is expected than in snow dominated environments (see Helmig et al., 2007b for a review of ozone dry deposition).

\section{Comparison between the South Pole and Concordia}

As already mentioned in Sect. 3.1, the seasonal cycle of ozone at Concordia, characterized by a maximum in July and followed by a decrease until October, and the occurrence of a secondary maximum in November-December, is similar to what is observed at the South Pole. As seen in Fig. 13 monthly mean ozone mixing ratios observed near the surface in November and December at the South Pole slightly exceed those observed at Concordia. Over the 2007-2014 period, the South Pole experienced, in November and December, 22 days with daily mean mixing ratios higher than $40 \mathrm{ppbv}$, compared to 1 day at Concordia, and 100 days with daily mixing ratios higher than $35 \mathrm{ppbv}$ compared to 35 days at Concordia. The reason for higher ozone values observed near the ground at the South Pole compared to those at Concordia is not simply related to the fact that solar radiation needed to photochemically produce ozone acts during $24 \mathrm{~h}$ at the South Pole and not at Concordia. Indeed, the two inland sites are expected to experience rather similar local photochemical ozone production, with $0.13-0.20 \mathrm{ppbv} \mathrm{h}^{-1}$ over $24 \mathrm{~h}$ at the South Pole (Chen et al., 2004) and from $0.05 \mathrm{ppbv} \mathrm{h}^{-1}$ at midnight to $0.27 \mathrm{ppbv} \mathrm{h}^{-1}$ during sunlight hours at Concordia (Kukui et al., 2014; see also Fig. 7c). As discussed below, the higher ozone values near the surface at the South Pole are primarily related to the difference in the dynamics of the lower atmosphere (more stratified lower atmospheric layers at the South Pole than at Concordia) rather than to the efficiency of the photochemistry. Notably, the South Pole also experiences more days with low values than Concordia, i.e., 34 days with daily mixing ratios lower than 22 ppbv compared to 13 days at Concordia. The larger number of days with low ozone levels at the South Pole than at Concordia is consistent with more frequent synoptic conditions bringing air masses having traveled mainly below $2500 \mathrm{~m}$ elevation to the site at the South Pole (Neff et al., 2008) than at Concordia.

The examination of the vertical distribution of ozone in summer at Concordia during sunlight hours and at the South Pole reveals several interesting differences. Concordia and the South Pole experience enrichment of ozone within the lowest few hundred meters above the ground with respect to typical background conditions (around $20 \mathrm{ppbv}$, Helmig et al., 2008). As reported by Oltmans et al. (2008), for a total of 215 summer balloon profiles at the South Pole between 1991 and 2005, a quarter of the profiles had no significant vertical gradients and a rather low ozone value near the surface (21 ppbv). Though fewer vertical profiles are available at Concordia, we never observed such an absence of ozone vertical gradient. This absence of days without ozone vertical gradients at Concordia is consistent with our previous observation of rare occurrence of days with near-surface mixing ratios lower than $21 \mathrm{ppbv}$ at that site compared to the South Pole.

When present, the vertical gradients are quite different between Concordia and the South Pole. As seen in Table 2, the enhanced ozone layer sometimes appears deeper at Concordia in the afternoon (up to $400 \mathrm{~m}$ ) than at the South Pole (from 60 to 200-250 m, Helmig et al., 2008; Oltmans et al., 2008). Furthermore, within the enhanced ozone layer, the ozone mixing ratios are more homogeneous at Concordia than at the South Pole. In fact, at the South Pole ozone is only homogeneously distributed within the lowest tens of meters above the ground, with the layers above always showing a steady ozone decrease down to the values observed within free troposphere layers (Table 2). At Concordia, the transition between high ozone values near the surface and background free tropospheric levels is often less than $100 \mathrm{~m}$. It therefore appears that the vertical stability of the enriched ozone layer is very different at the two sites. In contrast to conditions experienced at the South Pole, where there is no diurnal cycle, at Concordia during sunlight hours the tem- 
Table 2. Comparison of typical vertical gradient of ozone above the ground at Concordia in summer in the afternoon and those observed at the South Pole. Heights are given in ma.g.l. For the South Pole, we report the composite based on 88 profiles obtained during summer months between 1991 and 2005 showing vertical gradient of more than 8 ppbv (Oltmans et al., 2008) and the case of 24 December 2003 characterized by a mixing ratio close to $50 \mathrm{ppbv}$ near the surface, reported by Helmig et al. (2008).

\begin{tabular}{|c|c|c|}
\hline Site (launch time) & Ozone mixing ratio within the $\mathrm{PBL}$ & Ozone mixing ratio above the $\mathrm{PBL}$ \\
\hline $\begin{array}{l}\text { Concordia } \\
\text { (29 December 2009, 16:53) }\end{array}$ & $\begin{array}{l}22.1 \pm 0.15 \text { ppbv } \\
(0-405 \text { m a.g.l. })\end{array}$ & $\begin{array}{l}16.5 \pm 1.3 \text { ppbv } \\
(485-925 \text { m a.g.1.) }\end{array}$ \\
\hline $\begin{array}{l}\text { Concordia } \\
\text { (31 December 2009, 15:30) }\end{array}$ & $\begin{array}{l}19.4 \pm 0.14 \text { ppbv } \\
\text { (0-395 m a.g.l.) }\end{array}$ & $\begin{array}{l}16.6 \pm 0.13 \text { ppbv } \\
(465-585 \text { m a.g.1. })\end{array}$ \\
\hline $\begin{array}{l}\text { Concordia } \\
\text { (4 January 2010, 14:35) }\end{array}$ & $\begin{array}{l}33.0 \pm 0.5 \text { ppbv } \\
(0-248 \text { m a.g.1. })\end{array}$ & $\begin{array}{l}20.8 \pm 1.7 \text { ppbv } \\
(343-1010 \text { m a.g.1.) }\end{array}$ \\
\hline $\begin{array}{l}\text { Concordia } \\
\text { (11 December 2011, 14:54) }\end{array}$ & $\begin{array}{l}34.0 \pm 1.1 \text { ppbv } \\
(0-223 \text { m a.g.1. })\end{array}$ & $\begin{array}{l}25.1 \pm 2.0 \text { ppbv } \\
(235-755 \text { m a.g.1. })\end{array}$ \\
\hline $\begin{array}{l}\text { South Pole } \\
\text { (24 December 2003) }\end{array}$ & $\begin{array}{l}48.0 \pm 0.5 \mathrm{ppbv} \\
(0-50 \mathrm{~m} \text { a.g.1. }) \\
40.0 \mathrm{ppbv}(100 \mathrm{~m} \text { a.g.1. }) \\
32.5 \mathrm{ppbv}(150 \mathrm{~m} \text { a.g.1. }) \\
27.5 \mathrm{ppbv}(170 \mathrm{~m} \text { a.g.1. })\end{array}$ & $\begin{array}{l}24.0 \text { ppbv } \\
(170-500 \text { m a.g.1.) }\end{array}$ \\
\hline $\begin{array}{l}\text { South Pole } \\
\text { (composite picture from } 88 \text { profiles } \\
\text { in summer) }\end{array}$ & $\begin{array}{l}32.7 \pm 0.2 \text { ppbv } \\
(0-50 \text { m a.g.1.) } \\
31.5 \text { ppbv ( } 100 \mathrm{~m} \text { a.g.1.) } \\
29.8 \text { ppbv ( } 150 \mathrm{~m} \text { a.g.1.) } \\
26.3 \text { ppbv ( } 250 \mathrm{~m} \text { a.g.1.) } \\
24.0 \text { ppbv ( } 350 \mathrm{~m} \text { a.g.1.) }\end{array}$ & $\begin{array}{l}22.0 \text { ppbv } \\
(450-950 \text { m a.g.1.) }\end{array}$ \\
\hline
\end{tabular}

peratures are warmer just above the snow surface than in the upper layers. This leads to a vanishing of the stratification of the lower atmospheric layers at Concordia during sunlight hours. Furthermore, the role of large-scale dynamical processes, for example the subsidence in the polar cell and the subsequent adiabatic warming of the air, increasing with altitude, is relatively more important in the absence of the diurnal cycle, and this favors the stratification of the atmosphere. Finally, the fact that the South Pole is situated on a slope favors wind shear and mechanical turbulence and this somewhat limits the building of a strong stratification. More details on these different conditions can be found in Neff et al. (2008) and Gallée et al. (2015b). Finally, note that at Concordia the stratification of the lower layers occurred only at night but the photochemistry is not efficient at that time of the day.

\section{Comparison between the coastal sites Neumayer, Halley, Syowa, and Dumont d'Urville}

While the seasonal cycles at the four coastal sites are similar, and all display seasonal maxima close to $35 \mathrm{ppbv}$ in July (Fig. 13), there are some differences during mid-summer and spring. The summer values differ among sites, for instance with a mean December value close to $15 \mathrm{ppbv}$ at
NM (16.2 ppbv) and HA (15.1 ppbv), compared to $20 \mathrm{ppbv}$ at DDU. This difference is reduced when days with air transport to DDU from above $3000 \mathrm{~m}$ elevation are discarded (16.1 ppbv instead of $20.0 \mathrm{ppbv}$ ). The same is observed in November with a DDU mean value of $24.2 \mathrm{ppbv}$ (22.0 ppbv without considering air masses coming from the high plateau), compared to $20.7 \mathrm{ppbv}$ at NM. The case of SY appears to be intermediate with November and December values of 22.7 and $18.2 \mathrm{ppbv}$, respectively.

The larger day-to-day summer variability in ozone at DDU compared to that at other coastal sites (Fig. 13) is also evidenced by examining the frequency distribution of daily values observed in December at the four coastal sites (Fig. 14). While all sites display maximum occurrences of ozone mixing ratios between 15 and $19 \mathrm{ppbv}$, more high ozone values (17\% above 25 ppbv, $33 \%$ above 22 ppbv) are observed at DDU compared to NM (1\% above 25 ppbv, $5 \%$ above 22 ppbv) and HA (less than $1 \%$ above 25 ppbv, $1 \%$ above $22 \mathrm{ppbv})$. For the case of SY, an intermediate situation is observed with $2.5 \%$ of values above 25 ppbv, and $12 \%$ of values above 22 ppbv. These differences suggest that ozone-rich air masses present over the inland Antarctic plateau are more efficiently transported to DDU than to NM and HA. Figure 1 shows that the near-surface airflow between the Antarctic plateau and the coastal regions is largely controlled by 

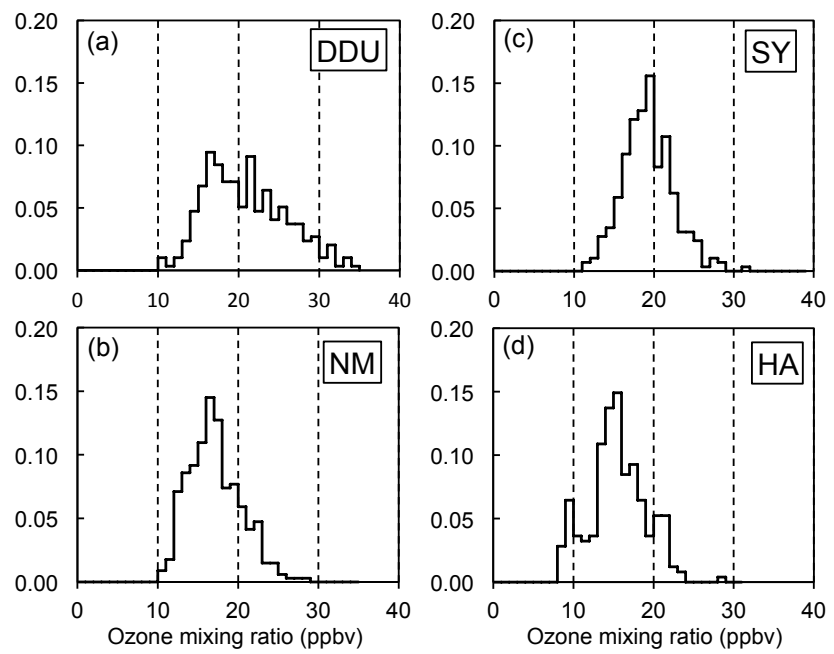

Figure 14. Frequency distribution of daily averaged $\mathrm{O}_{3}$ mixing ratios observed in December (2004-2014) at the coastal sites of Dumont d'Urville (a), Neumayer (b), Syowa (c), and Halley (d).

the topography of the underlying ice sheets and the vicinity of low pressure systems on the coast of the Antarctic continent (Parish and Bromwich, 2007). Consequently, the airflow coming from inland Antarctica is important at DDU and to a lesser extent at SY, but not at NM and HA.

In spring, a particularly high day-to-day variability can be observed from August to October at the two western coastal sites of NM and HA (Fig. 13). As seen in Fig. 15, this high variability of values is primarily due to occurrence of low ozone mixing ratios. Fewer low ozone values (less than $1 \%$ below $22 \mathrm{ppbv}$ ) are observed at DDU over these 3 months compared to NM ( $11 \%$ below 22 ppbv) and HA ( $18 \%$ below 22 ppbv). Note that no significant difference was observed when DDU daily values were calculated without removing hourly values suspected to be contaminated (i.e., lower ozone values, see Sect. 2). Thus, no bias due to inadequate removal of low values may have caused the observed absence of ozone values lower than $20 \mathrm{ppbv}$ at that site. At NM in spring, Frieß et al. (2004) examined surface ozone data and differential optical absorption spectroscopy (DOAS) observations of $\mathrm{BrO}$ along with the time air masses were located close to the sea ice surface as determined using back trajectory calculations. They showed that whereas ozone levels remain close to a typical spring background level of $30 \mathrm{ppbv}$ in air masses that have been in short contact with sea ice (less than 20h), severe ozone depletions are observed in air masses that have been in contact with sea ice for a long time (down to $5 \mathrm{ppbv}$ of ozone for air masses having sea ice contact of 5 days) in relation with the bromine chemistry (Fan and Jacob, 1992).

At DDU, with a sea ice extent offshore from the site of around $450 \mathrm{~km}(\sim 1 / 3$ compared to NM, see Fig. 1), a long time contact of air masses with sea ice is very rare. In Oc-
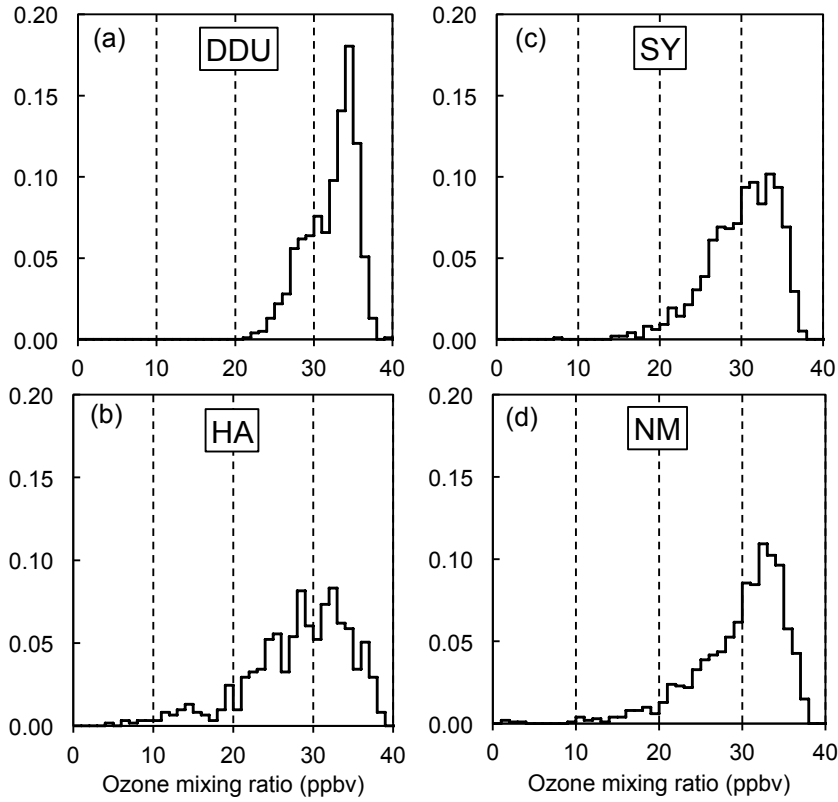

Figure 15. Frequency distribution of daily averaged ozone mixing ratios observed in August, September, and October (2004-2014) the coastal sites of Dumont d'Urville (a), Halley (b), Syowa (c), and Neumayer (d).

tober, for instance, only on five occasions had the air masses reaching DDU over the course of a whole day traveled exclusively over the ocean during the 5 days prior to their arrival. The contact time of air with sea ice shown by the backward trajectory was twice $10 \mathrm{~h}$, twice $20 \mathrm{~h}$, and once $60 \mathrm{~h}$.

For the case of SY, an intermediate situation is observed with $6.6 \%$ of values below $22 \mathrm{ppbv}$. These inter-site differences in spring clearly correlate with the extent of the sea ice area located offshore from the site with a minimum offshore DDU and a maximum offshore HA (see Fig. 1). It is interesting that most values around $15 \mathrm{ppbv}$ were encountered at HA in October at the time that surface $\mathrm{BrO}$ mixing ratios were found to reach a maximum (Saiz-Lopez et al., 2007).

\section{Long-term changes of ozone over the last decade}

The long-term ozone trends at the two East Antarctic sites were examined by calculating the regression line slopes through annual and/or monthly mean values. At Concordia, no annual analysis was done since a significant portion of summer measurements was missed (in 2007, 2008, 2009, 2011, and 2013). At DDU, a very weak annual increasing rate of $0.07 \pm 0.07 \mathrm{ppbv} \mathrm{yr}^{-1}$ is calculated, however the regression line slope was found to be not statistically different from zero at the $P>95 \%$ confidence level. The mean slopes of the linear regression lines calculated for each month are reported in Fig. 16 together with those calculated over the similar time period (from July 2004 to 2014) at SP, SY, NM, 

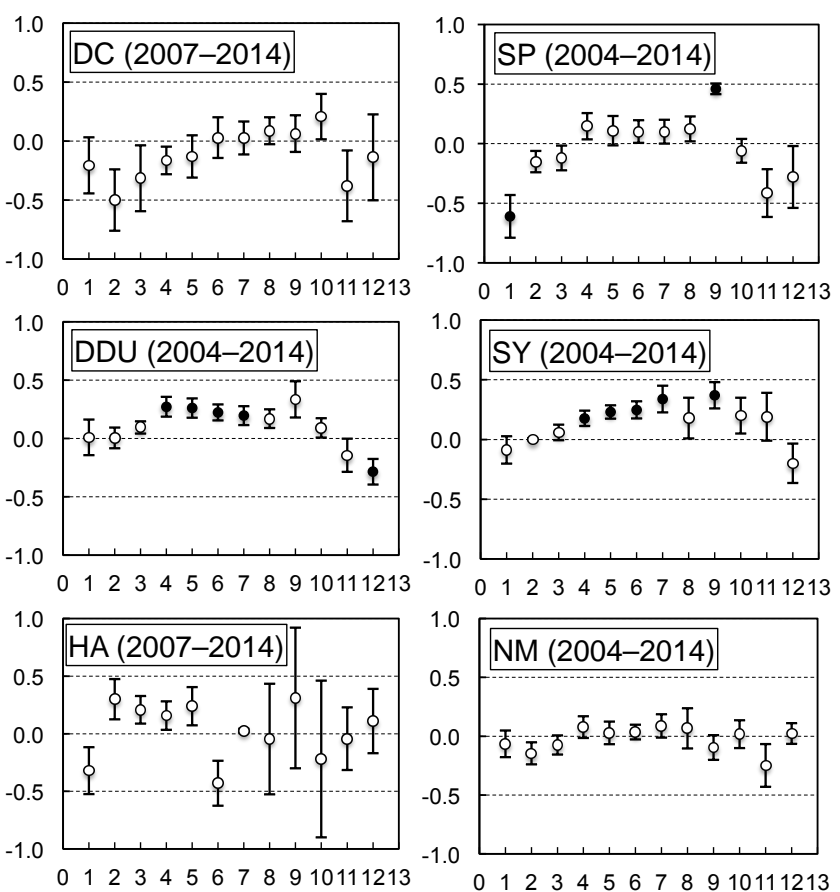

Figure 16. Monthly slopes of the linear regression lines of ozone trends analyses (in ppbv $\mathrm{yr}^{-1}$ ) at Concordia (DC), South Pole (SP), Dumont d'Urville (DDU), Syowa (SY), Halley (HA), and Neumayer (NM). Black circles denote slope values that are statistically different from zero at $P>95 \%$. Vertical bars refer to standard errors of the regression lines.

and HA. It can be seen that, at Concordia and DDU, a decreasing change is detected in summer (from November to February) and an increasing trend in winter.

Discarding from discussions the case of HA, for which the uncertainties of the regression line slopes are rather high, other sites sometimes exhibit decreasing changes that become statistically different from zero at the $P>95 \%$ confidence level only in December at DDU and in January at the South Pole. At Concordia, as discussed in Sect. 3.1.1, a large part of the inter-annual monthly variability in summer can be attributed to difference in synoptic transport of air masses over the Antarctic continent prior to arrival at the site. A good example of the role of transport is seen in November, for which a relatively strong decreasing change of $0.4 \pm 0.3 \mathrm{ppbv} \mathrm{yr}^{-1}$ is calculated (Fig. 16). As seen in Fig. 2, the decrease in November over the 2007-2014 time period at Concordia is mainly driven by the occurrence of the highest value (33.1 ppbv) encountered in 2007 and of the lowest value (27.2 ppbv) in 2013. At DDU, the decreasing change detected in December is also partly due the fact that the 2 recent years experienced low values: in 2013, due to a particularly high fraction of marine air arriving (44\% of time instead of $17 \pm 3 \%$ over other years, not shown), and in 2012, due to a low contribution of air masses coming from the high plateau ( $10 \%$ instead of $19 \pm 4 \%$ over other years, not shown).

Though being often not significantly different from zero at the $P>95 \%$ confidence level, the recent decreasing changes in surface ozone (2004-2014 and 2007-2014) detected in summer differ from those reported by Helmig et al. (2007a) who showed significant increasing trends in summer particularly at SP from 1975 to 2005 . Similarly to Concordia, synoptic transport conditions were shown to influence surface ozone at SP (Helmig et al., 2008). Therefore, the reversal of the surface ozone change over the last decades at SP, i.e., an increase between 1975 and 2005 and a decrease thereafter, may reflect a modification of synoptic transport favoring a larger impact of air masses coming from the highest part of the plateau from 1975 to 2005 and less from 2005 to 2014. Another parameter that has be considered when discussing changes over the last 4 decades is the total ozone column whose variations may modify the amount of UV radiation reaching the ground and thus $\mathrm{NO}_{x}$ snow emission rates and ozone photochemical productions. At the SP, the total ozone column (TOC expressed in DU) in January decreased at a rate of 1.6 DU per year from 1975 to 2004 (TOC $=-1.6 \times+307$ with $\left.R^{2}=0.77\right)$ but has increased at a rate of 2.1 DU per year from 2004 to 2014 (TOC $=2.1 \times+262$ with $\left.R^{2}=0.41\right)$. Note that it is unclear if the changes in the total ozone column at the SP in January are related to an ongoing recovery of the spring stratospheric layer. Indeed, in October the total ozone column decreased at a rate of 4.2 DU per year from 1975 to 2004 (TOC $=-4.2 \times+251$ with $R^{2}=0.53$ ) and the change became slower (but not yet reversed) between 2004 and 2014 (TOC $=2.7 \times+147$ with $\left.R^{2}=0.098\right)$. Though the link between the total ozone column and surface ozone mixing ratios is complicated since other factors (snow nitrate concentration, atmospheric mixing, snowfall, etc.) influence snow $\mathrm{NO}_{x}$ emission rates (Frey et al., 2015), we cannot totally rule out that, in addition to synoptic transport conditions, changing total ozone column may have contributed to the change detected in surface ozone over the last decades. Finally, the observation of a significant recent summer decreasing change at DDU in December (Fig. 16) is consistent with the site being influenced by processes acting in inland Antarctica. On the other hand, the weaker decreasing change in summer calculated for other coastal sites like NM and SY (Fig. 16) is also consistent with a weaker impact of oxidantrich inland air masses at these two coastal sites, as previously discussed in Sect. 5.

The increase of ozone during winter seen at all sites (except at HA) over the 2004-2014 and 2007-2014 time periods is a quite interesting observation (Fig. 16). Whereas none of the increasing winter changes were found to be statistically different from zero at the $P>95 \%$ confidence level at Concordia, at DDU, increasing trends that range between 0.2 and $0.3 \mathrm{ppbv} \mathrm{yr}^{-1}$ are statistically different from zero at the $P>95 \%$ confidence level from April to July. Ozone changes are not significantly different from zero at 
South Pole and Neumayer, but interestingly, as for DDU, they are significant at Syowa. Given the lack of solar irradiance during the winter months in Antarctica, local photochemical processes are unlikely to have an influence. Therefore, it seems more probable that this ozone increase reflects changes in stratosphere-troposphere (or synoptic transport of ozone-enriched air to these sites) and/or change in the stratospheric ozone reservoir. That motivates further work to extend the time series and examine the role of these parameters that are expected to control the budget of surface ozone at the surface in winter.

\section{Concluding remarks}

Recently obtained surface ozone measurements at the coastal site of Dumont d'Urville and the inland Concordia station allowed extending data from ongoing measurements made at the South Pole and at several coastal sites located either in West Antarctica (Neumayer and Halley) or northern (Syowa) and southern (McMurdo) East Antarctica. Similar features in the occurrence of high ozone events as at the South Pole are observed at the inland site of Concordia in summer. However, near-surface values exceed $40 \mathrm{ppbv}$ at the South Pole but not at Concordia. Investigation of the vertical ozone distribution at the two sites indicates that the differences at the surface are related to boundary layer dynamics, in particular the presence of diurnal radiation and temperature cycles at Concordia, which are lacking at SP, and associated cycles of boundary layer stability and mixing. We present indications for decreasing surface ozone changes in the summer at the Concordia and SP over the most recent observation periods (2004-2014 and 2007-2014). Though synoptic transport largely influences ozone at the two sites, we cannot rule out that this change in surface ozone in summer is also related to an increase of the stratospheric ozone layer and associated reduction in $\mathrm{NO}_{x}$ photochemical production from the snow, $\mathrm{NO}_{x}$ emissions from the snowpack, and resulting ozone photochemical production. The unique character of DDU with respect to other coastal Antarctic sites is emphasized by its susceptibility to inland $\mathrm{NO}_{x}$ chemistry, showing consistently a decreasing change in summer over the 2004-2014 and 2007-2014 years in accordance with the inland sites. On the other hand, the DDU ozone record shows a weaker signal of bromine chemistry than at Halley and Neumayer in spring. Finally, the DDU data indicate a significant increasing trend in winter, motivating the extension of time series in view to examine the possible influence of stratosphere-troposphere transport.

\section{Data availability}

The surface ozone data from the South Pole, Syowa, Neumayer, and Halley used in this study are available at the WMO World Data Centre for Greenhouse
Gases (http://ds.data.jma.go.jp/gmd/wdcgg/cgi-bin/wdcgg). Surface ozone data from Concordia and Dumont d'Urville can be made available for scientific purposes upon request to the authors. Total ozone column data from the South Pole are available from Earth System Research Laboratory (Global monitoring division, http://www.esrl.noaa.gov/ gmd/dv/data/) (Petropavlovskikh, I., Oltmans, S. J. (2012), Dobson Total Ozone measurements, version: 2013-02-25, path:ftp://aftp.cmdl.noaa.gov/data/ozwv/Dobson).

Acknowledgements. The OPALE project was funded by the ANR (Agence National de Recherche) through contract ANR09-BLAN-0226. National financial support and field logistic supplies for the summer campaign were provided by the Institut Polaire Français-Paul Emile Victor (IPEV) through program nos. 414 and 903. This work was initiated in the framework of the French environmental observation service CESOA (Etude du cycle atmosphérique du Soufre en relation avec le climat aux moyennes et hautes latitudes Sud, http://www-lgge.obs.ujf-grenoble.fr/CESOA/spip.php?rubrique2) with the financial support of INSU (CNRS). Detlev Helmig's contribution was funded by the USA National Science Foundation grant PLR 1142145. We also thank the researchers and agencies that conducted the ozone measurements at Syowa, Neumayer, and the South Pole and making them available for their dissemination in the World Data Centre for Greenhouse Gases. We thank Marie Dumont from Centre d'étude de la neige (CEN/Météo-France) and Giuseppe Camporeale from ENEA who contributed to balloon soundings done in summer 2009-2010. We also thank Christophe Genthon from LGGE, who provided us the Vaisala PTU sondes in the frame of the Concordiasi program, and Marion Marchand from LATMOS, who provided us the ozone sondes and calibration system in the frame of the program IPEV no. 912 during summer 2009-2010. We thank the two anonymous reviewers and the editor for their helpful comments.

Edited by: J. W. Bottenheim

\section{References}

Barrie, L. and Platt, U.: Arctic tropospheric chemistry: an overview, Tellus 49B, 450-454, 1997.

Berresheim, H. and Eisele, F. L.: Sulfur Chemistry in the Antarctic Troposphere Experiment: An overview of project SCATE, J. Geophys. Res., 103, 1619-1627, doi:10.1029/97JD00103, 1998.

Bottenheim, J. W., Gallant, A. G., and Brice, K. A.: Measurements of $\mathrm{NO}_{y}$ species and $\mathrm{O}_{3}$ at $82^{\circ} \mathrm{N}$ latitude, Geophys. Res. Lett. 13, 113-116, 1986.

Chen, G., Davis, D., Crawford, J., Hutterli, L. M., Huey, L. G., Slusher, D., Mauldin, L., Eisele, F., Tanner, D., Dibb, J., Buhr, M., McConnell, J., Lefer, B., Shetter, R., Blake, D., Song, C. H., Lombardi, K., and Arnold, J.: A reassessment of HOx South Pole chemistry based on observations recorded during ISCAT 2000 , Atmos. Environ., 38, 5451-5461, 2004.

Crawford, J. H., Davis, D. D., Chen, G., Buhr, M., Oltmans, S., Weller, R., Mauldin, L., Eisele, F., Shetter, R., Lefer, B., Arimoto, 
R., and Hogan, A.: Evidence for photochemical production of ozone at the South Pole surface, Geophys. Res. Lett., 28, 36413644, 2001.

Davis, D. D., Nowak, L. B., Chen, G., Buhr, M., Arimoto, R., Hogan, A., Eisele, F., Mauldin, L., Tanner, D., Shetter, R., Lefer, B., and McMurry, P.: Unexpected high levels of NO observed at South Pole, Geophys. Res. Lett., 28, 3625-3628, 2001.

Davis, D. D., Eisele, F., Chen, G., Crawford, J., Huey, G., Tanner, D., Slusher, D., Mauldin, L., Oncley, S., Lenschow, D., Semmer, S., Shetter, R., Lefer, B., Arimoto, R., Hogan, A., Grube, P., Lazzara, M., Bandy, A., Thornton, D., Berresheim, H., Bingemer, H., Hutterli, M., McConnell, J., Bales, R., Dibb, J., Buhr, M., Parko, J., McMurry, P., Swanson, A., Meinardi, S., and Blake, D.: An overview of ISCAT 2000, Atmos. Environ., 38, 53635373, doi:10.1016/j.atmosenv.2004.05.037, 2004.

Eisele, F., Davis, D. D., Helmig, D., Oltmans, S. J., Neff, W., Huey, G., Tanner, D., Chen, G., Crawford, J., Arimoto, R., Buhr, M., Mauldin, L., Hutterli, M., Dibb, J., Blake, D., Brooks, S. B., Johnson, B., Roberts, J. M., Wang, Yu., Tan, D., and Flocke, F: Antarctic tropospheric chemistry investigation (ANTCI) 2003 overview, Atmos. Environ., 42, 2749-2761, doi:10.1016/j.atmosenv.2007.04.013, 2008.

Fan, S. M. and Jacob, D.J. : Surface ozone depletion in the Arctic spring sustained by bromine reactions on aerosols, Nature, 359, 522-524, 1992.

Frey, M. M., Steward, R. W., McConnell, J. R., and Bales, R. C.: Atmospheric hydroperoxides in West Antarctica: Links to stratospheric ozone atmospheric oxidation capacity, J. Geophys. Res., 110, D23301, doi:10.1029/2005JD006110, 2005.

Frey, M. M., Roscoe, H. K., Kukui, A., Savarino, J., France, J. L., King, M. D., Legrand, M., and Preunkert, S.: Atmospheric nitrogen oxides (NO and $\mathrm{NO}_{2}$ ) at Dome $\mathrm{C}$, East Antarctica, during the OPALE campaign, Atmos. Chem. Phys., 15, 7859-7875, doi:10.5194/acp-15-7859-2015, 2015.

Frieß, U., Hollwedel, J., König-Langlo, G., Wagner, T., and Platt, U.: Dynamics and chemistry of tropospheric bromine explosion events in the Antarctic coastal region, J. Geophys. Res., 109, D06305, doi:10.1029/2003JD004133, 2004.

Gallée, H., Preunkert, S., Argentini, S., Frey, M. M., Genthon, C., Jourdain, B., Pietroni, I., Casasanta, G., Barral, H., Vignon, E., Amory, C., and Legrand, M.: Characterization of the boundary layer at Dome C (East Antarctica) during the OPALE summer campaign, Atmos. Chem. Phys., 15, 62256236, doi:10.5194/acp-15-6225-2015, 2015a.

Gallée, H., Barral, H., Vignon, E., and Genthon, C.: A case study of a low-level jet during OPALE, Atmos. Chem. Phys., 15, 62376246, doi:10.5194/acp-15-6237-2015, 2015 b.

Grilli, R., Legrand, M., Kukui, A., Méjean, G., Preunkert, S., and Romanini, D.: First investigations of $\mathrm{IO}, \mathrm{BrO}$, and $\mathrm{NO}_{2}$ summer atmospheric levels at a coastal East Antarctic site using modelocked cavity enhanced absorption spectroscopy, Geophys. Res. Lett., 40, 1-6, doi:10.1002/grl.50154, 2013.

Helmig, D., Oltmans, S. J., Carlson, D., Lamarque, J. F., Jones, A., Labuschagne, C., Anlauf, K., and Hayden, K.: A review of surface ozone in the polar regions, Atmos. Environ., 41, 5138-5161, doi:10.1016/j.atmosenv.2006.09.053, 2007a.

Helmig, D., Ganzeveld, L., Butler, T., and Oltmans, S. J.: The role of ozone atmosphere-snow gas exchange on polar, boundary-layer tropospheric ozone - a review and sensitivity analysis, Atmos. Chem. Phys., 7, 15-30, doi:10.5194/acp-7-15-2007, 2007b.

Helmig, D., Johnson, B., Oltmans, S. J., Neff, W., Eisele, F., and Davis, D. D.: Elevated ozone in the boundary layer at South Pole, Atmos. Environ., 42, 2788-2803, doi:10.1016/j.atmosenv.2006.12.032, 2008.

Honrath, R. E., Peterson, M. C., Guo, S., Dibb, J. E., Shepson, P. B., and Campbell, B.: Evidence of NO production within or upon ice particles in the Greenland snowpack, Geophys. Res. Lett., 26, 695-698, 1999.

Jones, A. E., Weller, R., Minikin, A., Wolff, E. W., Sturges, W. T., McIntyre, H. P., Leonard, S. R., Schrems, O., and Bauguitte, S.: Oxidized nitrogen chemistry and speciation in the Antarctic troposphere, J. Geophys. Res., 104, 21355-21366, 1999.

Jones, A. E., Weller, R., Wolff, E. W., and Jacobi, H. W.: Speciation and rate of photochemical $\mathrm{NO}$ and $\mathrm{NO}_{2}$ production in Antarctic snow, Geophys. Res. Lett., 27, 345-348, 2000.

Jones, A. E., Weller, R., Anderson, P. S., Jacobi, H. W., Wolff, E. W., Schrems, O., and Miller, H.: Measurements of $\mathrm{NO}_{x}$ emissions from the Antarctic snowpack, Geophys. Res. Lett., 28, 14991502, 2001.

Jones, A. E. and Wolff, E. W.: An analysis of the oxidation potential of the South Pole boundary layer and the influence of stratospheric ozone depletion, J. Geophys. Res., 108, 4565, doi:10.1029/2003JD003379, 2003.

Jones, A. E., Wolff, E. W., Salmon, R. A., Bauguitte, S. J.-B., Roscoe, H. K., Anderson, P. S., Ames, D., Clemitshaw, K. C., Fleming, Z. L., Bloss, W. J., Heard, D. E., Lee, J. D., Read, K. A., Hamer, P., Shallcross, D. E., Jackson, A. V., Walker, S. L., Lewis, A. C., Mills, G. P., Plane, J. M. C., Saiz-Lopez, A., Sturges, W. T., and Worton, D. R.: Chemistry of the Antarctic Boundary Layer and the Interface with Snow: an overview of the CHABLIS campaign, Atmos. Chem. Phys., 8, 3789-3803, doi:10.5194/acp-8-3789-2008, 2008.

Kukui, A., Legrand, M., Ancellet, G., Gros, V., Bekki, S., SardaEstève, R., Loisil, R., and Preunkert, S.: Measurements of $\mathrm{OH}$ and $\mathrm{RO}_{2}$ radicals at the coastal Antarctic site of Dumont d'Urville (East Antarctica) in summer, J. Geophys. Res., 117, D12310, doi:10.1029/2012JD017614, 2012

Kukui, A., Legrand, M., Preunkert, S., Frey, M. M., Loisil, R., Gil Roca, J., Jourdain, B., King, M. D., France, J. L., and Ancellet, G.: Measurements of $\mathrm{OH}$ and $\mathrm{RO}_{2}$ radicals at Dome C, East Antarctica, Atmos. Chem. Phys., 14, 12373-12392, doi:10.5194/acp-14-12373-2014, 2014.

Legrand, M., Preunkert, S., Jourdain, B., Gallée, H., Goutail, F., Weller, R., and Savarino, J.: Year-round record of surface ozone at coastal (Dumont d'Urville) and inland (Concordia) sites in East Antarctica, J. Geophys. Res. Atmos., 114, D20306, doi:10.1029/2008JD011667, 2009.

Masclin, S., Frey, M. M., Rogge, W. F., and Bales, R. C.: Atmospheric nitric oxide and ozone at the WAIS Divide deep coring site: a discussion of local sources and transport in West Antarctica, Atmos. Chem. Phys., 13, 8857-8877, doi:10.5194/acp-138857-2013, 2013.

McClure-Begley, A., Petropavlovskikh, I., and Oltmans, S.: NOAA Global Monitoring Surface Ozone Network, 1973-2014, National Oceanic and Atmospheric Administration, Earth Systems Research Laboratory Global Monitoring Division, Boulder, CO, doi:10.7289/V57P8WBF, 2014. 
Neff, W., Helmig, D., Grachev, A., and Davis, D.: A study of boundary layer behavior associated with high NO concentrations at the South Pole using a minisodar, tethered balloons and sonic anemometer, Atmos. Environ., 42, 2762-2779, 2008.

Oltmans, S. J., Schnell, R. C., Sheridan, P. J., Peterson, R. E., Li, S.-M., Winchester, J. W., Tans, P. P., Sturges, W. T., Kahl, J. D., and Barrie, L. A.: Seasonal surface ozone and filterable bromine relationship in the high Arctic, Atmos. Environ., 23, 2431-2441, 1989.

Oltmans, S. J., Johnson, B. J., and Helmig, D.: Episodes of high surface ozone amounts at South Pole during summer and their impact on the long-term ozone variation, Atmos. Environ., 42, 2804-2816, doi:10.1016/j.atmosenv.2007.01.020, 2008.

Oltmans, S. J., Johnson, B. J., and Harris, J. M.: Springtime boundary layer ozone depletion at Barrow, Alaska: Meteorological influence, year-to-year variation, and long-term change, J. Geophys. Res., 117, D00R18, doi:10.1029/2011JD016889, 2012.
Parish, T. R. and Bromwich, D. H.: Reexamination of the nearsurface airflow over the Antarctic continent and implications on atmospheric circulations at high southern latitudes, Mon. Weather Rev., 135, 1961-1973, 2007.

Preunkert S., Ancellet, G., Legrand, M., Kukui, A., Kerbrat, M., Sarda-Estève, R., Gros, V., and Jourdain, B.: Oxidant Production over Antarctic Land and its Export (OPALE) project: An overview of the 2010-2011 summer campaign, J. Geophys. Res., 117, D15307, doi:10.1029/2011JD017145, 2012.

Saiz-Lopez, A., Mahajan, A. S., Salmon, R. A., Bauguitte, S. J.B., Jones, A. E., Roscoe, H. K., and Plane, J. M. C.: Boundary layer halogens in coastal Antarctica, Science, 317, 348-351, doi:10.1126/science.1141408, 2007.

Stein, A. F., Draxler, R. R, Rolph, G. D., Stunder, B. J. B., Cohen, M. D., and Ngan, F.: NOAA's HYSPLIT atmospheric transport and dispersion modeling system, B. Am. Meteorol. Soc., 96 , 2059-2077, doi:10.1175/BAMS-D-14-00110.1, 2015. 